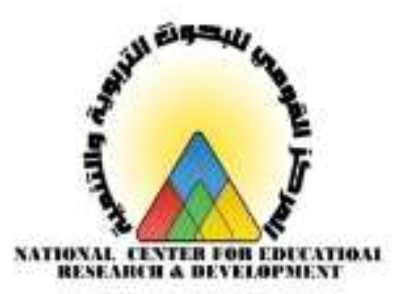

\title{
إطار مقترح لدمج معايير الروبوت في مناهج العلوم والرياضيات بالمرحلة الإعدادية
}

\author{
إ
}

د/شيماء حموده الحارون دكتور باحث بالمركز القومي

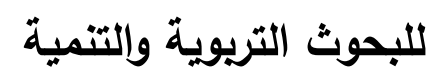

\author{
د/ أمل الشحات حافظ \\ استاذ باحث مساعد بالمركز \\ القومي للبحوث التريوية والتنمية باحية
}

\author{
الناش \\ المكز التومي للبحوث التربويته قالثميت بالتاهنة \\ جمهورية مصر العربية
}

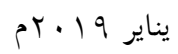




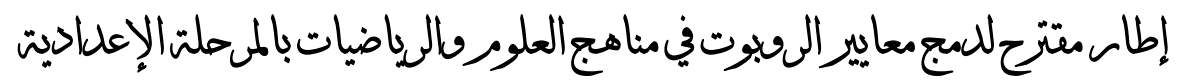

\section{إطار هقترح للدهج همعايير الروبرت \\ في هناهج العلوم والرياضيات بالمرحلة الإعدادية}

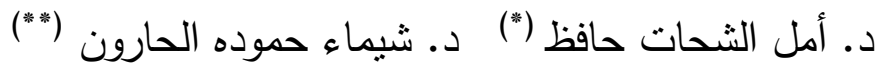

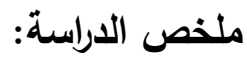

هدفت الدراسـة الحالية إلى تحديد معايير الروبوت التي يمكن دمجها في منـاهج العلوم والرياضيات بمرحلة التعليم الإعدادي بمصر ؛ ولتحقيق ذلك الهدف تم تحليل محتوى كتب العلوم والرياضيات الحالية في هذه المرحلة لتحديد مدى توافر مفاهيم ومهارات شُسهم في تعلم الروبوت، ووصف لكيفيـة دمـج هذه المعايير في منـاهج

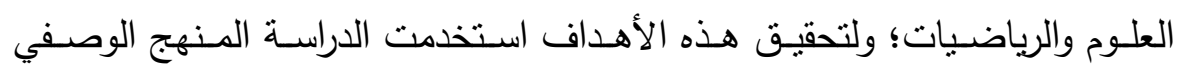
التحليلي للوصول إلى معايير الروبوت، وتم تحليل محتوى كتب العلوم والرياضيات بمرحلة التعليم الإعدادي والتي بلغ عددها (7) كتب دراسية في مادة العلوم، و (آ) كتب دراسية في مادة الرياضيات بحيث كان لكل صف دراسي كتابين (فصل دراسي ودي أول وفصـل دراسـي ثـاني)، وأظهـرت نتـائج التحليـل عـدم تتـاول أبي مـن مفــاهيم الروبوت أو مهاراته بصورة مباشرة واضحة في كتب العلوم والرباضيات، وبناء على ورفي

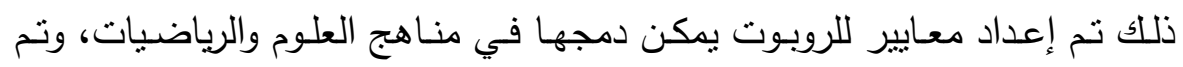

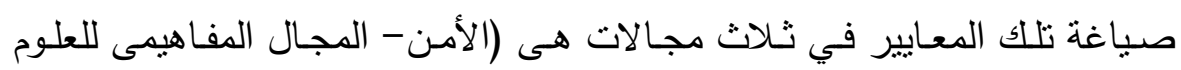

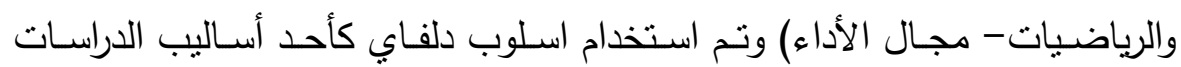

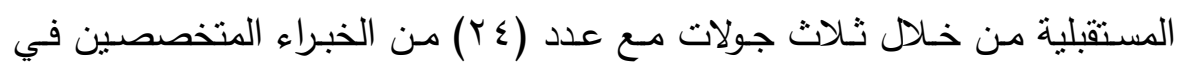

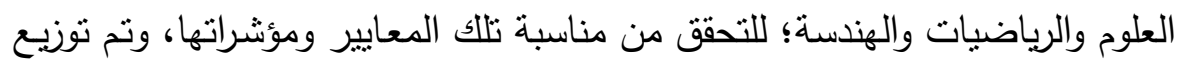

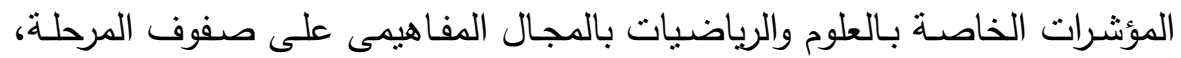

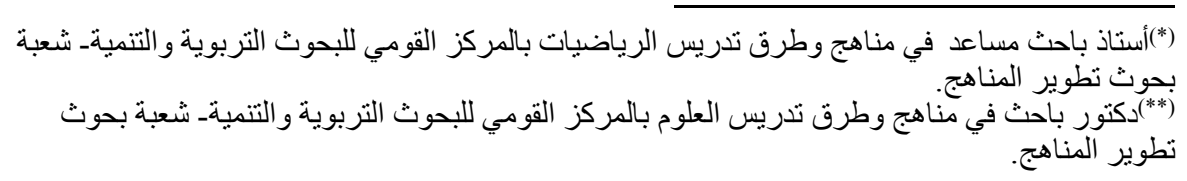
. $r \leqslant$. 


$$
\begin{aligned}
& \text { ولمسـاعدة المعلمين واكمـال تصـور دمهج تلك المعـايير بالمنـاهج تم إعداد تصـور } \\
& \text { مقترح لوحدة دراسية تتضمن مجموعة من الموضوعات يمكن أن يدرسها معلم العلوم } \\
& \text { والرياضيات يوظف من خلالها مجموعة من مفاهيم الروبوت ومهاراته. } \\
& \text { الكلمات المفتاحية: معايير الروبوت، مناهج العلوم، مناهج الرياضيات. }
\end{aligned}
$$

Proposed Framework for Incorporating Robot Standards into Science and Mathematics Curriculum in the Preparatory Stage Dr. Amal Al-Shahat Hafez ${ }^{(*)}$ Dr. Shaimaa Hamouda El-Haroun ${ }^{(* *)}$ Summary:

The aim of this study is to determine the criteria for robotics that can be integrated into science and mathematics preparatory stage curricula. In order to achieve this objective, the content of current science and mathematics textbooks has been analyzed at this stage to determine the availability of concepts and skills that contribute to robot learning. The study used the analytical descriptive approach to reach the robot standards. The science and mathematics books that were analyzed include (6) textbooks in science, (6) textbooks in mathematics, The results of the analysis showed that none of the robot concepts or skills were directly covered in science and mathematics textbooks, Accordingly, standards for robots that could be integrated into science and mathematics curricula were developed and formulated in Three fields (security - the conceptual field of science and mathematics - the field of performance) and used the method of Delphi - as one of the methods of future studies through three rounds with (24) experts in science, mathematics and engineering to verify the suitability of these criteria and indicators. The indicators of science and mathematics were distributed in the conceptual field to the students of the stage.

To assist teachers and to complete the integration of those standards into curricula, a proposed concept for a module has been developed that includes a set of subjects that can be taught by the science and mathematics teacher, employing a set of robot concepts and skills.

Keywords: robot standards, science curriculum, mathematics curriculum.

${ }^{(*)}$ Assistant Professor in National center For Educational research and Development

${ }^{(* *)}$ Researcher in National center For Educational research and Development

$$
\text { . ro. }
$$




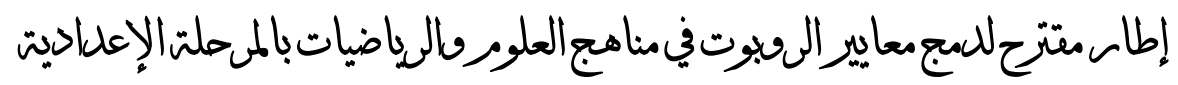

\section{إطار هقتزح لدهم همايير الروبوت}

\section{في هناهج العلوم والرياضيات بالمرحلة الإعدادية}

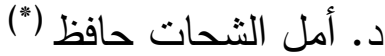

د. شيماء حموده الحارون (**")

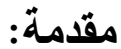

يتسم العصر الحالي بأنه عصر تقنية المعلومات والتحول من اقتصاد الموجودات إلى اقتصـاد المعلومات، أو الاقتصـاد القائم على المعرفة الذي فئه

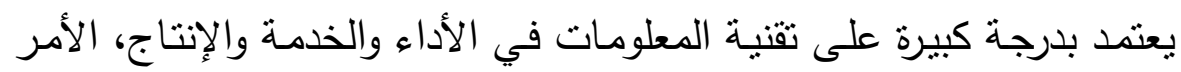

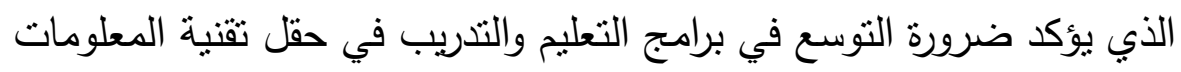

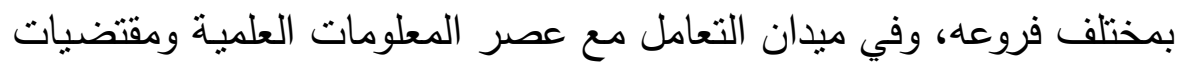

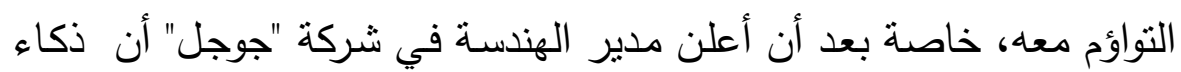
الآلات سيصل إلى مستويات أقوى بمليارات المرات من الذكاء البشري.

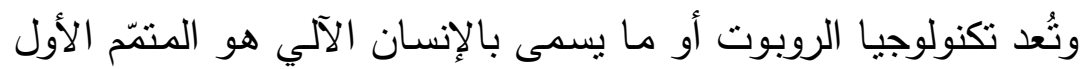

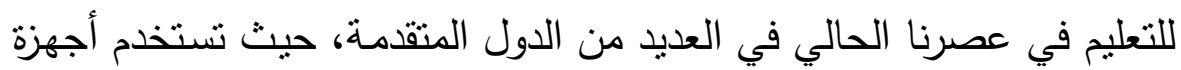

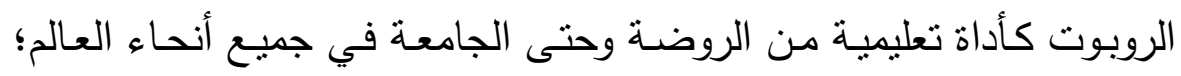

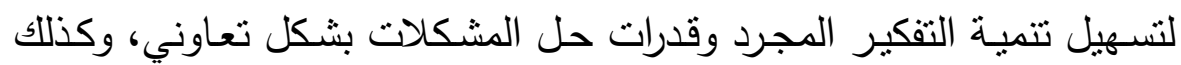

(*)(أستاذ باحث مساعد في مناهج وطرق تدريس الرياضيات بالمركز القومي للبحوث التربوية والتنميةـ شعبة بحوث تطوير المناهج. تطوير المناهج. . Y 


\section{المركن القومي للبحوث التبويةوالتنمية}

دعم التعلم في مختلف التخصصات العلمية والأدبية والفنية المنصوص عليها (Bredenfeld, et.al., 2010; Catlin \& في المناهج الدراسية Balmires, 2010). إن اسـتخدام الروبـوت وانتشـاره في العديد مـن المجـالات يستثير لـى المتعلمين الرغبة لفهم كيف تعمل؟ ولماذا؟ حيث يُطلب منهم تصميم روبوت ذاتي الحركة، وبناءه وبرمجتة ويتطلب ذلك من المتعلم التفكير في تصـيم وتتفيذ الروبوت والبرنامج الذى يُمكن الروبوت من أداء مهمة مكانية أو حسية أو حركية، فبناء الروبوت يطرح عددًا من التحديات التي تتطلب من المتعلمين الاعتماد على قدرات التفكير وحل المشكلات المجردة، منها على سبيل المثنال التفكير في الموارد المتاحة (من حيث مكونات الروبوت وأوامر البرمجة)، ثم التبؤ بنتـائج اختبـارات البنـاء وبرامجهـا، والتخطيط لسلسـلة مـن التعليمـات، ومراقبة نتائج خططهم، ومقارنتها مسع الأهداف المرجو تحقيقها لتحقيق نتائج (Cincelli, et.al., 2010; Norton, et.al., 2006; Denis, أفضل 2001).

ولقد أصبح الروبوت حالياً واحد من أكثر تقنيات الذكاء الاصطناعي تقدمًا من حيث التطبيقات التي تقدم فيها حلوًا كاملة للمشكلات، بحيث أصبح لله أهميه كبيرة في الحياة وفي المجالات العلمية والصناعية والطبية وغيرها من المجالات، لذا يجب الاتفاق على أنه لايتم تدريس علم الروبوت لتخربج متخصصين بعلم الروبوت؛ بل لمساعدة المتعلمين على فهم التصميم الهندسي والعالم الرقمي الذي ينتمون إليه. 


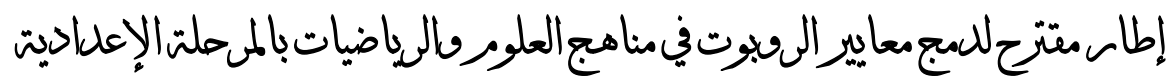

حيث يمكن لمعلم العلوم أن بستخدم علم الروبوت لتطبيـق كل من

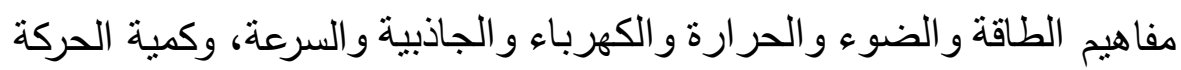

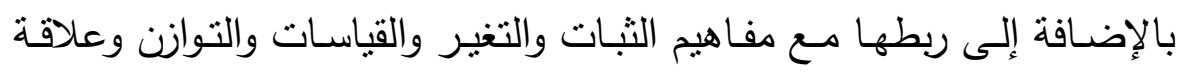
الثكل بالوظيفة، ويُمكن لمعلم الرياضيات أن يستخدم علم الروبوت ليُمرّن

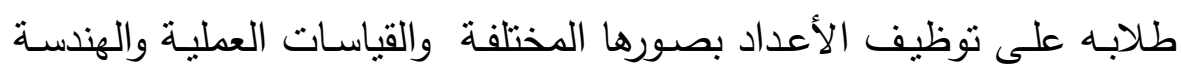

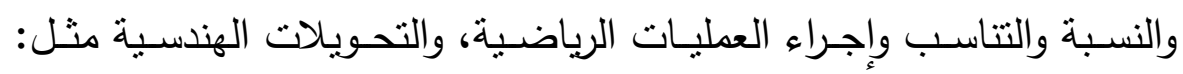

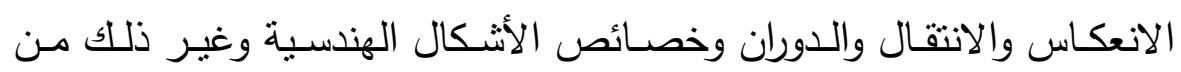

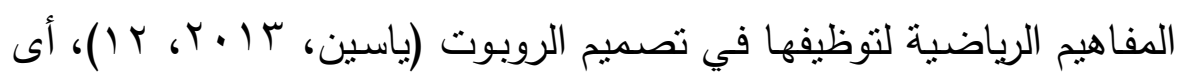

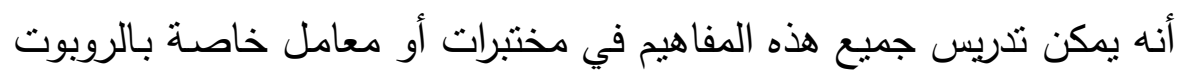

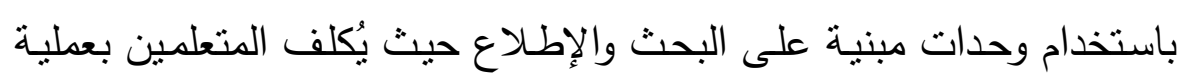
جمع وتتظيم وتصنيف البيانات بطرق مختلفة وصولًا إلى ملخص لها تُسهم

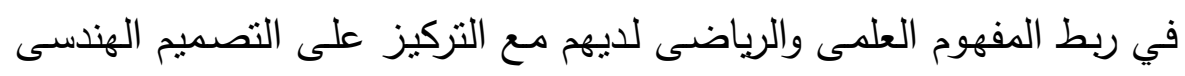
أو التحكم الرقمى (Soares, et al, 2011).

فكلما استطاع المتعلمين الربط بين الأثياء أمكنهم تتمية معرفتهم وزاد

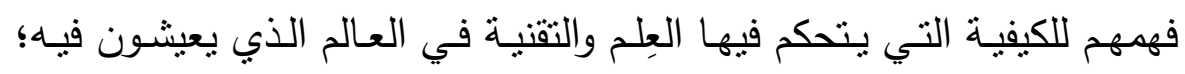

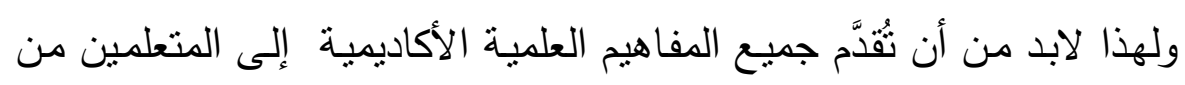

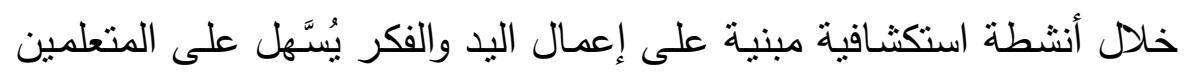

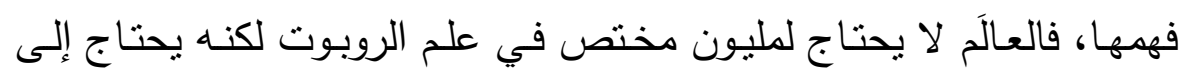
جيل كفء علميًا ورياضيًا ومتعلم تقنيًا لحل المشكلات التي قد نواجها البشرية

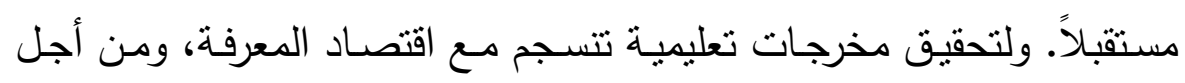
. YA. 


\section{المركن القومي للبحوث التبويةوالتنمية}

مواكبة معطيات العصر لامتلاك المهارات اللازمة لدخول مجالات التكنولوجيا الحديثة سـعت الـدول العربيـة لنشـر ثقافـة الروبـوت ودعم مشـروع الروبـوت التعليمي في المدارس من خلال برامج دراسية خاصة بالروبوت لتتمية مهارات التفكير الإبداعي وحل المشكلات والقدرة على التحليل لدى المتعلمين، ويحتوي مضمون هذه البرامج على مفاهيم الروبوت وأنواعـه ومكوناته كما تتاح هذه البرامج للمتعلمين الراغبين في دخول كليات الهندسة والحاسب الآلي (مؤسسة

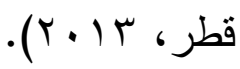

ولقد كان لشركة LEGO ليغو العالمية للألعاب عام 99 ام الدور

الرائد في تصميم أول روبوت تعليمي حيث تم عقد عدة اتفاقيات مـع بعض الشركات العالمية المتخصصة كمعهد MITT وشركة ليغو First LEGO LEGO League وتم إنتاج مجموعة من حقائب الروبوت عُرفت باسم Mind Storms والهندية، ثم أُجري تعاون بين شركة First وشركة LEGO لإطلاق أول بطولة عالمية لتصميم الروبوت وبرمجتها وذلك للأطفال والثباب من عمر 9 وحتى عمر 17 سنة وتم تسمية البطولة (FLL) ومنذ عام 999 ام وحتى اليوم والبطولـة مستمرة وتثـهد نزايداً كبيراً بعدد الفرق والدول المشـاركة كما

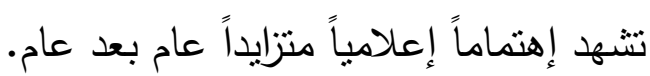
وأصبحت مسابقة الروبوت للأطفال (FLL) مسابقة عالمية في مجال برمجة علوم الروبوت والهندسة تقام للمرة الثانية على التوالي في الاردن لعام

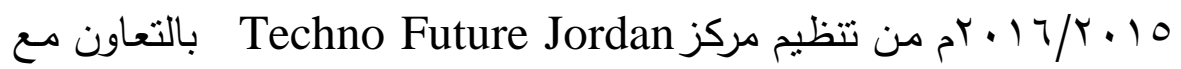




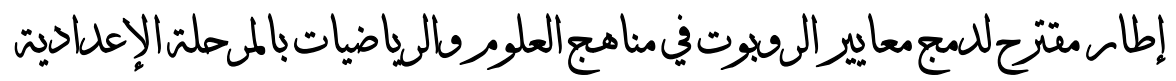

مركز اليوبيل للتميز التربوي حيث تطرح المسابقة مشكلة حقيقية يقوم الأطفال

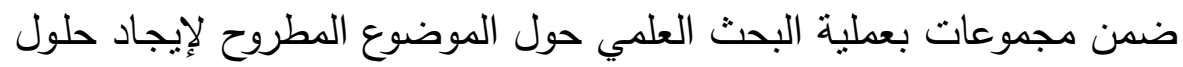
ومقترحات جديدة وعرض نتائج البحث من خلال تصميم وبناء نموذج متحرك .(Techno Future Jordan, 2015) وبالرجوع إلى خبرات بعض الدول العربية نجد أن وزارة التربية والتعليم الأردنية قررت منذ عام r ا ـ rم نشر ثقافة الروبوت، ولذلك قام مركز التميز

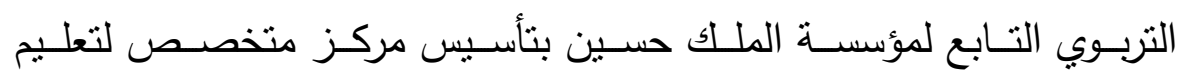

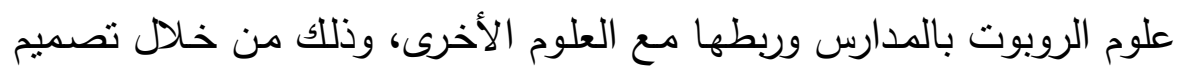

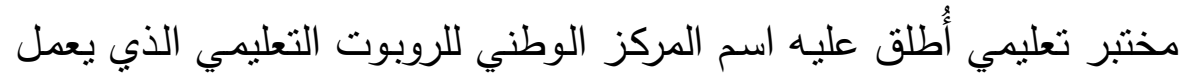

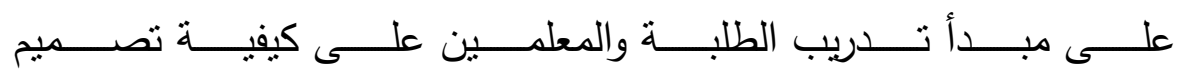
وبرمجة الروبوت وإدخاله في المناهج واستخدامه في التعليم، وقد تم تجهيز

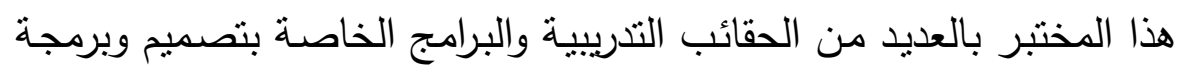

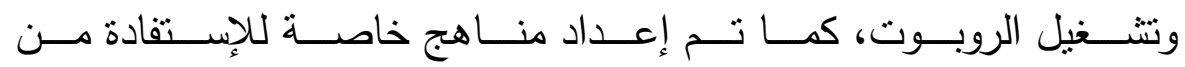
علوم الروبوت في تعليم الرياضيات والعلوم والتكنولوجيا.

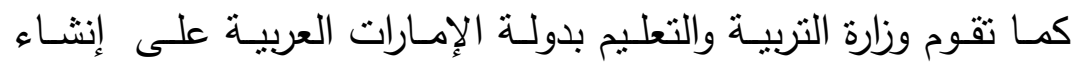
مختبرات للروبوت في جميع المدارس الحكومية في دبي والمناطق الثمالية لاستخدام الروبوت ضمن المناهج التعليمية، وذلك بعد نطبيق مبادرة استخدام

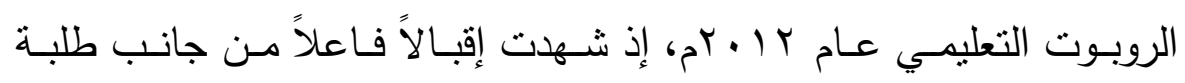
كثيرين، ونجحت الوزارة في تدريب معلمين عدة على استخدام الروبوت (وزارة

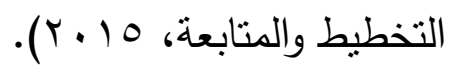
r. . 


\section{المركن القومي للبحوث التبويةوالتنمية}

وبـدأت وزارة التربيـة والتعليم بدولـة الكويـت في تطبيـق مشـروع مـنهج

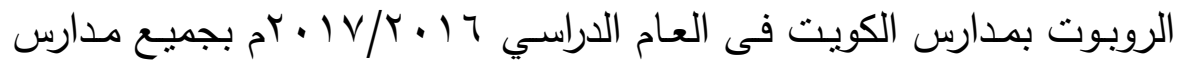
الكويت، كما ثُظظم وزارة التربية والتعليم بسلطنة عُمان مسابقة سنوياً لأولمبياد الروبوت الوطنيـة وهي من الأولمبيـاد العالميـة للروبـوت في سـلطنة عمـان World Oman, 2014) Robot Olympiad World Oman (WRO) .(Robot Olympiad أمـا في مصـر فقد نظم قطـاع التعليم الفـى بـوزارة التربيـة والتعليم

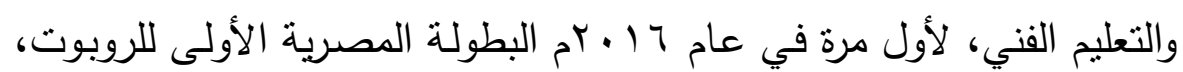
بالمدرسة الفنية المتقدمة لتكنولوجيا الصيانة، وبؤكد الدليل التتظيمى للبطولة أنها تهدف إلى تدريب طلاب التعليم الفنى على التكنولوجيا المستخدمة فى كيفيـة تصميم وبنـاء وبرمجـة الروبوت، وذللك من خـلال المشـاركة في أكبر VEX Robot مسابقة لصناعة الروبوت على مستوى العالم وهى مسابقة ‘(Egypt VEX Robotics Competition, 2016)Competition كما بدأت مدارس STEM للمتقوقين فى العلوم والتكنولوجيا فى تضمين مقرر اختيارى عن الروبوت.

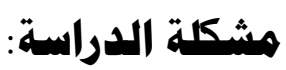

تهدف مصر في روية · ب • rم أن يكون المجتمع المصري بحلول عام

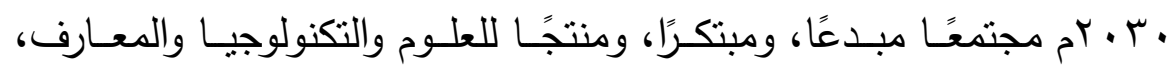
ويتميز بوجود نظام منكامل يضمن القيمة التموية للابتكار والمعرفة، ويربط تطبيقـات المعرفـة ومخرجـات الابتكـار بالأهـداف والتحـديات الوطنيـة وذلك 


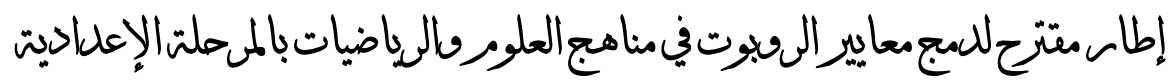

بتمكين المتعلمين مـن مهـارات الرياضـيات والعلوم وتكنولوجيـا المعلومـات والمشاركة في المسابقات الدولية.

وفي ضوء دراسة واقع الروبوت في بعض الدول العربية نجد أن الأردن

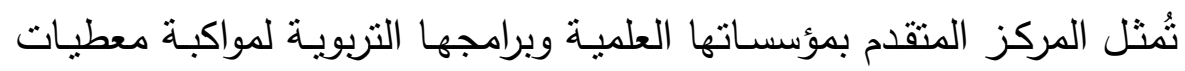

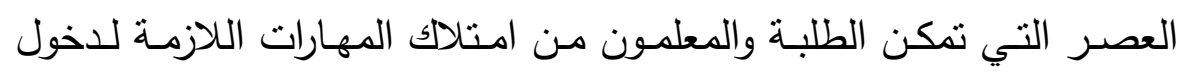

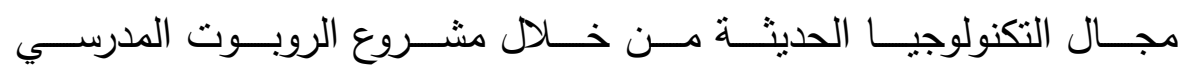

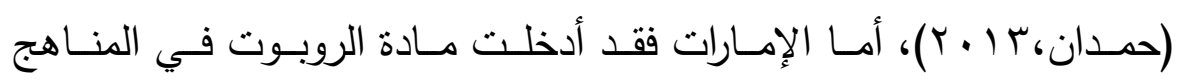

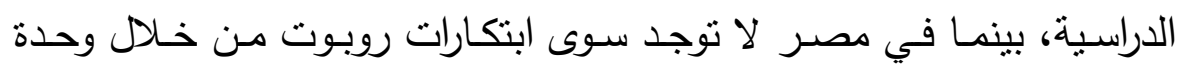

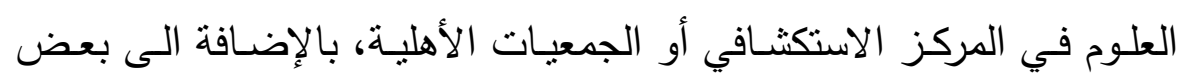

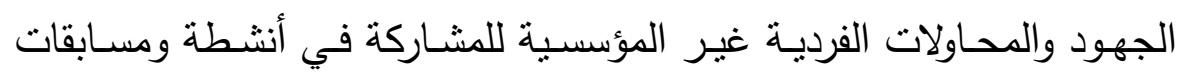
الروبوت لطلاب كليات الهنسـة، وبذلك نجد أن مناهجنا المصرية بمراحل التعليم قبل الجامعى تعاني من قصور في مفاهيم ومهارات تكنولوجيا الروبوت

$$
\text { والتي تهدف إلى: }
$$

توفير الفرصـة لطـلاب المدارس الواعدين لتوسيع آفاقهم من خـلال

$$
\text { اكتشاف الروبوت ونظامه وبرمجته. }
$$

تقديم مفاهيم العلوم الحديثة في الأنشطة التعليمية في مجالات العلوم

$$
\text { والرياضيات والتكنولوجيا. }
$$

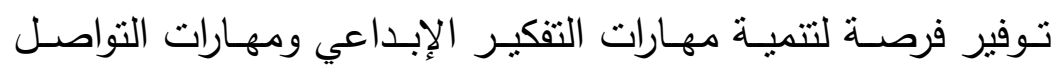
والتعاون، وتقوية القدرة على اكتساب معرفة جديدة ذات علاقة كبيرة بالثقام العلمي.

.r.

البحث التربوي 


\section{المركن القومي للبحوث التبويةوالتنمية}

تطوير مهارات الإبـداع وحل المشكلات لدى المتعلمين مـن خـلال المشــاركة في تحديات ومسـابقات الروبـوت على المسـتوى المحلى والعالمى.

توسيع نظرة المتعلمين في تطبيق العلوم، وتوظيف مفاهيم الرياضيات وتحسـين كفـاءة الـتعلم وتتــيع طلابنـا ليكونـوا علمــاء ومهندسـي

$$
\text { ومخترعي المستقبل. }
$$

وعند دراسـة الروبوت وتعليمه وتضـمينه في محتوى مـادة العلوم لا يمكن أن يستقل بذاته، ولكنه يحتاج إلى دراسة مجموعة من الحقائق والمفاهيم الرياضية مما يستلزم التكامل بين مادتي العلوم والرياضيات. وللتحقق مـن واقع علم الروبـوت ومفاهيمـه في محتوى مـادتي العلـوم والرياضيات بمرحلة التعليم الإعدادى قامت الباحثتان بتحليل محتوى المادتين من الصف الأول الى الصف الثالث الإعدادى، وأظهرت نتائج التحليل مـا يلى :

- ل ال يوجـد أي إثـارة لمفهوم الروبـوت ومهاراتهـ أو كيفيـة تصــيمه بصورة مباشرة في كتب العلوم بالمرحلة الإعدادية ولكن فقط يوجد

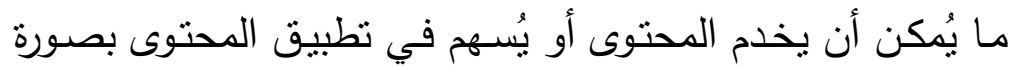
غير مباشـرة، ومنها على سبيل المثال: مفاهيم الحركة والسـرعة

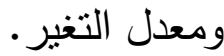
- - كما أظهر تحليل محتوى كتب مادة الرياضيات بالمرحلة الإعدادية توافر كافة المعايير الخاصة بالأعداد والجبر والهندسة والقياس إلا 


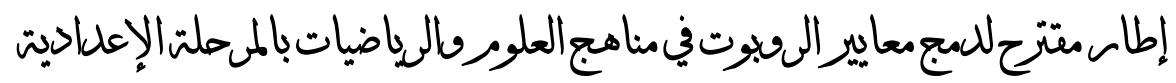

أنها تقدم بصورة رياضية مجردة تخلو من أى أنشطة أو تطبيقات

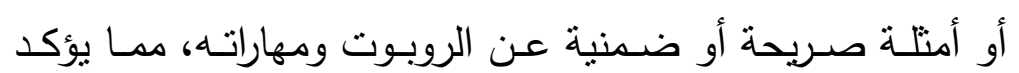

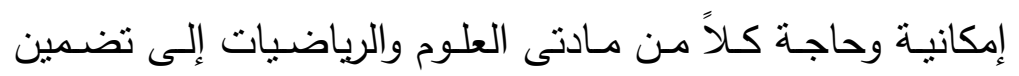
معايير الروبوت ومهارات في تللك المرحلة.

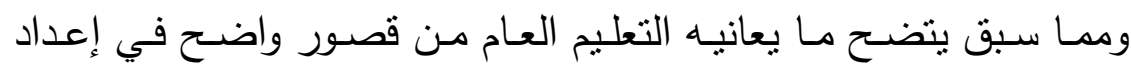

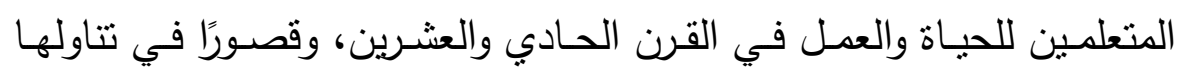

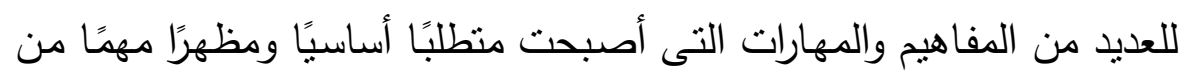
مظاهر التقدم العلمى والتى منها مفاهيم الروبوت ومهاراته، وعلى ذلك تبرز

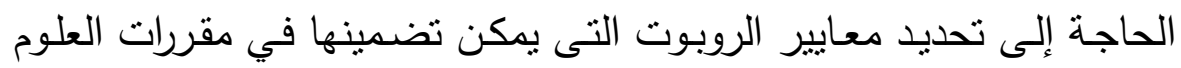

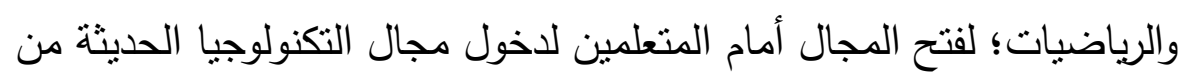
خلال مشروع الروبوت المدرسي.

وعليه تتبلور مشكلة الاراسة في السؤال الرئيس الآتي:

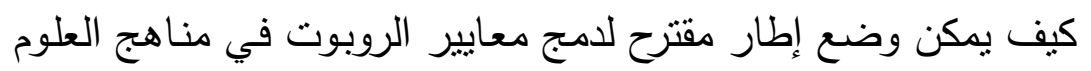
والرياضيات بالمرحلة الإعدادية؟ وضئ

ويتفرع من هذا السؤال الرئيس الأسئلة الفرعية الآتية:

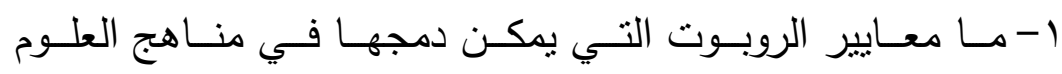

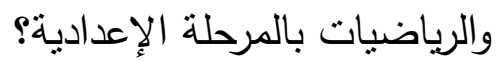

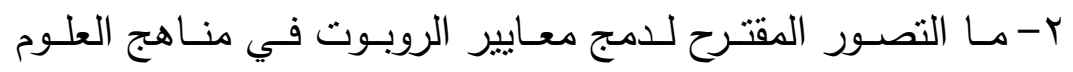

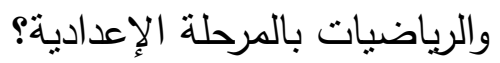




\section{المركن القومي للبحوث التبويةوالتنمية}

r- مـا التصـور المقترح لوحدة دراسـية فحى العلـوم والرياضـيات عـن

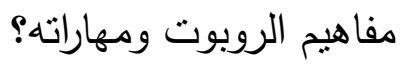

\section{أهميسة الدراسة: تتبع أهمية الدراسة من: \\ 1- الناحية النظرية:}

أ- توفر الدراسة الحالية نموذجًا لدمج معابير الروبوت في مناهج

$$
\text { العلوم والرياضيات في مرحلة التعليم الإعدادي. }
$$

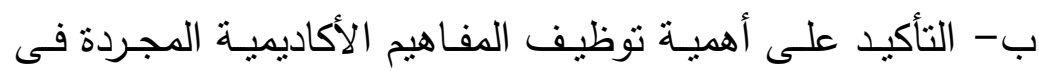

العلوم والرياضيات من خلال تطبيقات حديثة ومواكبة للنطور

$$
\text { المعرفى ومنها الروبوت. }
$$

ج- المساهمة في وضع المعايير الرئيسة للمهارات والمعلومات ذات الصلة بالروبوت تمهيدًا للإستقادة منها في تطوير مناهج العلوم

$$
\text { والرباضيات }
$$

د- تشــهيل مهمــة حصــول المعلـم علـى المعلومــات الخاصــة

بالروبوت، بالإضافة إلى أمثلة للأنشطة التعليمية التكاملية التى لهى

$$
\text { يمكن الاسترشاد بها لاستيفاء معايير الروبوت. }
$$

r -من الناحية التطبيقية: 


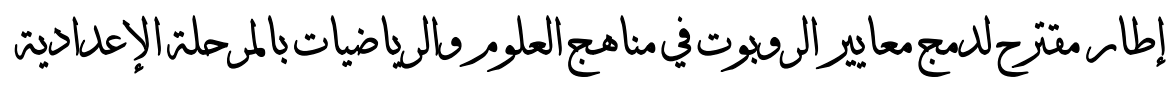

أ- ينعكس دمـج معـايير الروبوت في المنـاهج على إعداد أدلـة

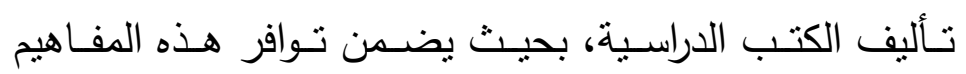

$$
\text { والمهارات في محتواها. }
$$

ب- يمكن الاستعانة بهذه الدراسة في بناء معايير الروبوت بمرحلة

التعليم الثانوي في مادني الفيزياء والكيمياء والميكانيكا.

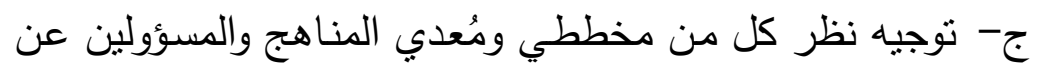

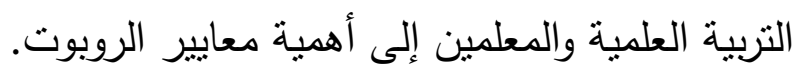

\section{أهداف الدراسة: تهدف الدراسة إلي:}

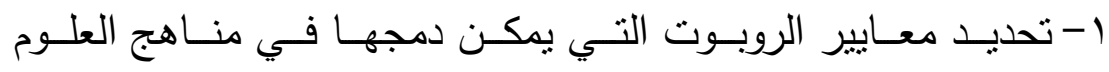

والرياضيات بالمرحلة الإعدادية.

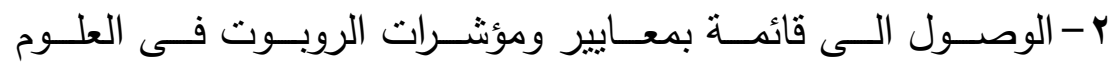

والرياضيات.

ץ-وصف لكيفية دمج معايير الروبوت في مناهج العلوم والرياضيات. ع - إعـداد وحدة دراسـية مقترحسة في العلـوم والرياضـيات عـن مفــاهيم الروبوت ومهاراته.

هدود الدراسة: تلتزم الدراسة بالحدود التالية: 1-معايير الروبوت لمرحلة التعليم الإعدادى.

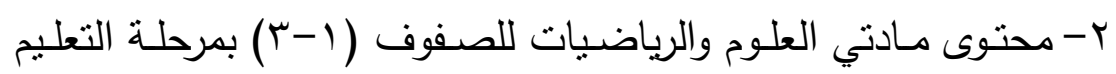

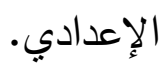

.r.

البحث التربوي 


\section{المركن القومي للبحوث التبويةوالتنمية}

ب- الصـفوف (1-ب) فـى مرحلـة التعليم الإعـدادي في مـادتي العلـوم

والرباضيات.

ع - وصـف الإطـار المقترح للدمج معـايير الروبـوت في محتوى منـاهج

العلوم والرياضيات بمرحلة التعليم الإعدادي.

\section{هم:}

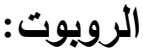

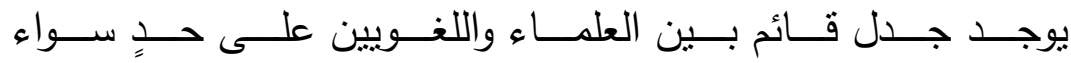

بشـأن التعربف الدقيق للروبوت، فالبعض يقوم بإطلاق هذه الصفة على كل آلة يُمكن للإنسـان السيطرة عليها وتحريكها عن بُعد، بينما لا يوافق البعض

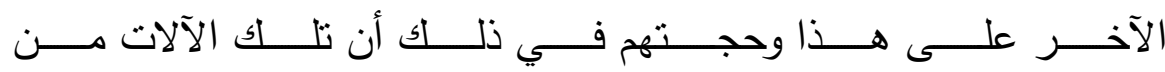
شاكلة السيارة أو الطائرة ذات التحكم عن بُعد، ولا يُمكن اعتبارها روبوت لعدم امتلاكها المقدرة على التفكير وإتخاذ القرار بنفسها(Polk,2005). ومع تعدد التعريفات المختلفة للروبوت إلا أن الخبراء يتفقون على أنّ الروبوت جهاز ميكانيكي قادر على تأديـة المهام بشكل تلقائي، بحيث يُنّذ الروبوت عادةً واحدة أو أكثر من المهام التالية :التحرك والاستشعار وإظهار السلوك الذكي، كما أنه يحتاج إلى الإرشاد إما من خلال برنامج أو من خلص

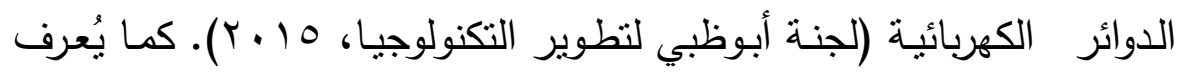
الإنسان الآلي أو الروبوت (بالإنجليزية:Robot) أنه أداة ميكانيكية قادرة على 


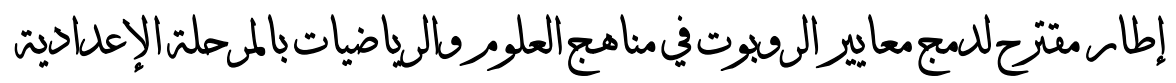

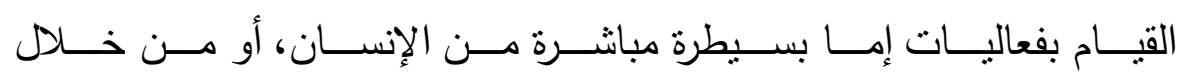

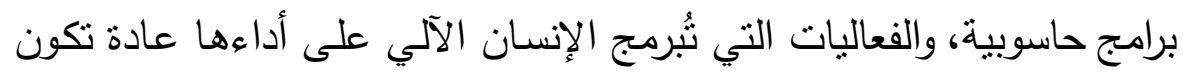

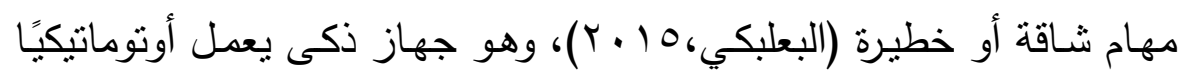

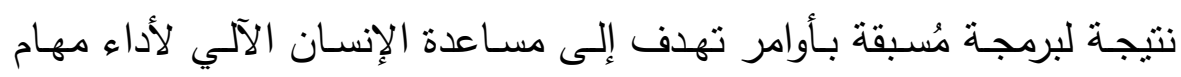

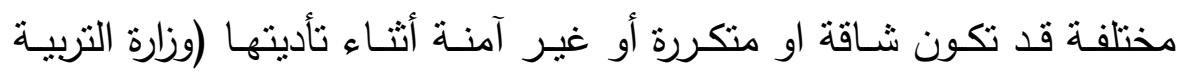

$$
\begin{aligned}
& \text { والتعليم بسلطنة عمان ، } 17 \text { (Y). } \\
& \text { - تعليم الرويوت: }
\end{aligned}
$$

ويقصد به إكساب المتعلمين القدرة على التعرّف إلى الوظائف المختلفة

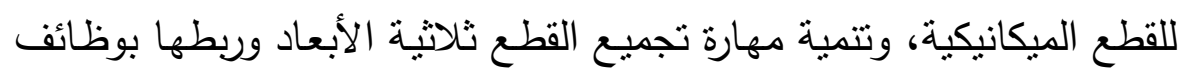

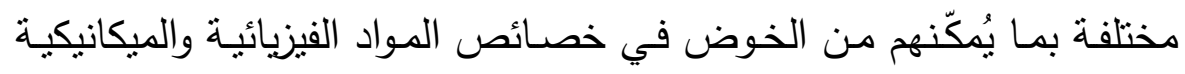

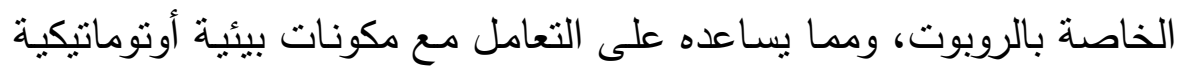

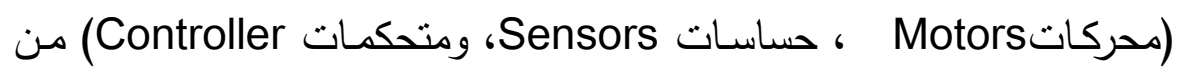
خلال توظيف مفاهيم ومهارات مادتي العلوم والرياضيات. - معايير الرويوت في مناهج العلوم والرياضيات:

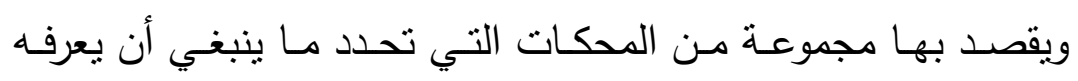

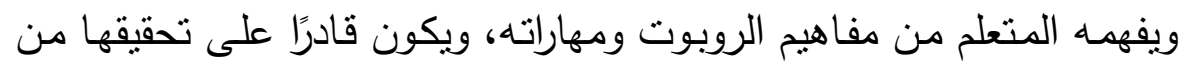

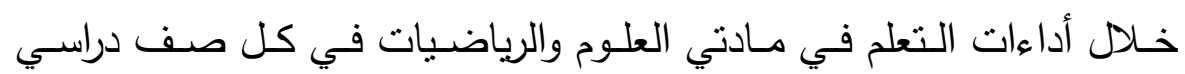
بالمرحلة الإعدادية.

\section{الإطار النظري والدراسات السابقة:}

. 


\section{المركن القومي للبحوث التبويةوالتنمية}

تتتـاول الدراسـة الحاليـة عدد مـن الأُطـر النظريـة الخاصـة بـالروبوت

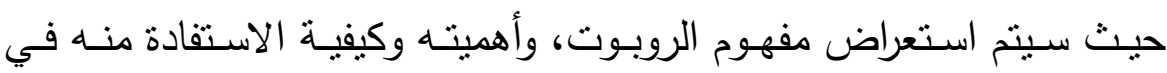
العملية التعليمية، وأسس ومعايير تعليم الروبوت في المدارس. الرويوث والعملية التعليمية:

عمل المهتمون في مجال التربية والتعليم على ايجاد وتوفير أساليب واستراتيجيات تعليم جديدة ومميزة ونوعيـة في سبيل الإرتقاء والوصـول إلى أفضل النتائج في أداء وتحصيل المتعلمين، وإعدادهم لسوق العدل المحلى والعـالمى، وقد سـاعدت التقنيات الحديثة وتكنولوجيا المعلومـات والاتصسالات على ايجـاد اسـتراتيجيات وطـرق وأسـاليب مـن شـأنها رفع مسـتوى المتعلمـين الأكـاديمي، وتحسـين أدائهم الدراسـي بالإضـافة إلى تتميـة مهـارات التفكيـر لديهم.

وترجع جذور الروبوت الحديث إلى أجهزة آلية اخترعت في الماضي البعيد وأطلـق عليها "الآلات ذاتيـة الحركة"، وكـان أول روبـوت فى التاربخ للعـالم المسـلم أبو العز الجزرى حيث ابتكر (آلة الوضوء) وهى عبارة عن إنسـان آلى يتحرك حركة ذاتيـة ويحمل بأحد يديـه إبريـق ماء وباليد الأخرى منشفة؛ ليتمكن الشخص من الوضوء بعد أن يصدر مُجسم لطائر صوت عند دخول وقت الصلاة، وفي اليونان في القرن الرابع ق.م. اخترع أركيتاس عالم الرياضيات حمامة آلية يُمكنها الطيران، وفي عام سم9 ام، عُرض للمواطنين في الولايات المتحدة أجهزة روبوت صغيرة متحركة منها روبوت يستخدم في المنازل، حيث تضمّنت مهامها المنزلية تتفيذ عدد محدد من الأعمال المفيدة 


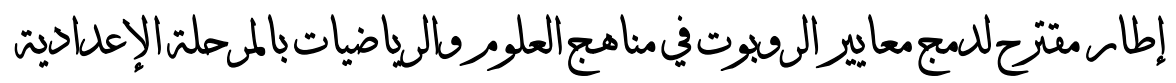

بالإضـافة إلـى اعتبارهـا أداةً مسـلّية (وزارة التربيـة والتعلـيم بسـلطنة عمـان، .$(Y \cdot) 17$

ولقد بدأ الروبوت التعليمى مع العقد الأول من القرن الحادي والعشرين

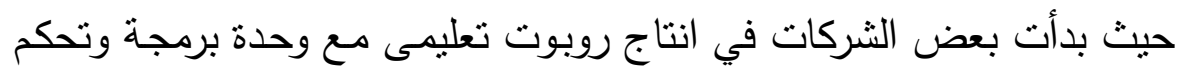

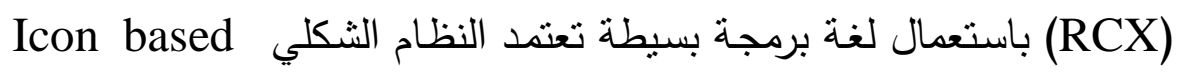

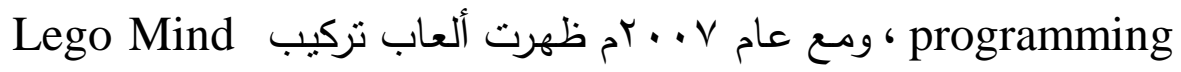

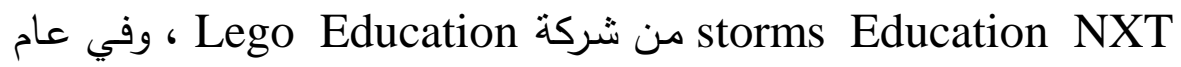

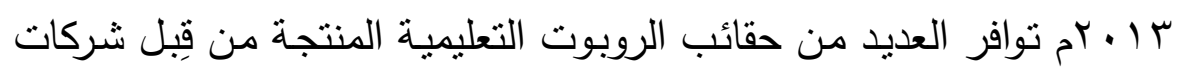

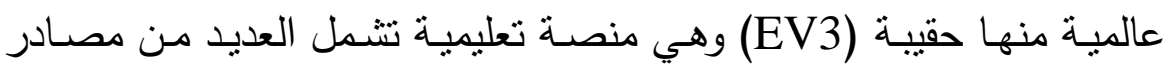

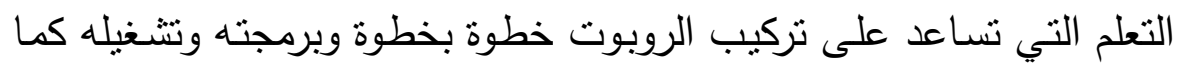
تتمل لغة برمجة مرئية سهلة الاستخدام، وتتكون الحقيبة من: وحدة البناء.

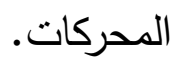

• المستشعرات (الموجات فوق الصوتية، الألوان، الدوران، اللمس) بطارية قابلة لإعادة الثحن.

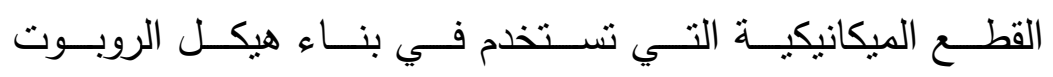

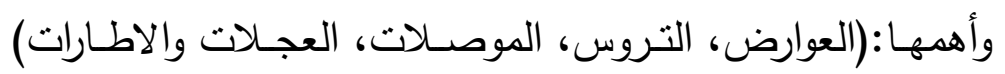
.(Lego Mindstorms, 2011) أما مهام الروبوت التعليمية فقد تحددت بشكل رئيس للمتطلبات المهنية

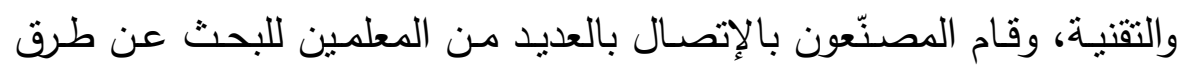




\section{المركن القومي للبحوث التبويةوالتنمية}

تقيدهم في استخدام منتجاتهم في النظام التعليمي( ويكيبيديا: الموسوعة الحرة، 7 ( ا ب)، وبالإعتمـاد على هذه الفكرة بدأ الباحثُون بتطوير طُرق تمكّنهم من اسـتخدام أجهـزة روبـوت صــيرة متحركـة كـأداة تعليميـة في مراحل التعلـيم الأساسـي والثانوى، وبذلك ظهر عددُ من الأبحاث الهادفة لتطوير المناهج، ولكنّ القليل منها كان قد اكتمل وأصبح متوفراً في الحقل التعليمي. وباعتبار الروبوت أحد المجالات الحديثة التى تحقق انتثار سربع في الأوسـاط التعليميـة، ولكونـهـ يُتيح للمتعلمـين الفـرص لتتفيذ أنشـطة مرتبطـة بتصميم وتركيب الروبوت، وتلك الأنشطة تبدأ من مفاهيم بسيطة يتعلمها المتعلم كمدخل لتعلم المبادئ الأساسية في العلوم والرياضيات، ولهذا فإن دور الروبوت كوسيلة تعليميـة عمليـة تفتح آفاقاً لا حدود لها للمتعلم؛ لكى يفكر ويصمم وينفذ ولكي يوظف المبادئ العلمية التى يعرفها ويبحث عن نلك التى لتى يحتاجها للوصول إلى هدفه (العبري، 1 • ( ). ولقد أكدت دراسـة نيميـرو وآخرون (Nemiro, et.al,2017) أنـه لتتميـة اهتمامـات المتعلمـين بالمرحلـة الابتدائيـة بمـواد العــوم والرياضـيات والتكنولوجيـا يكـون ذلـك مـن خـلال دمــج المتعلمـين في برنـامج الروبـوت والانخراط في تصميمات الروبوت لما بتميز به المتعلمين من درجة عالية من الطاقة من خلال عمهم المكثف على المهام الروبوتية وتحقيقهم لإبداعات من

$$
\text { منتجات الروبوت الإبداعية. }
$$

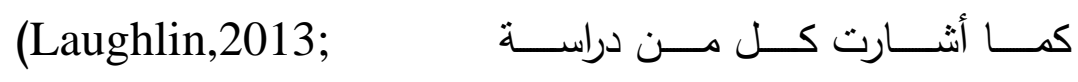

Chung,et.al.,2014; Bianco, 2014) 


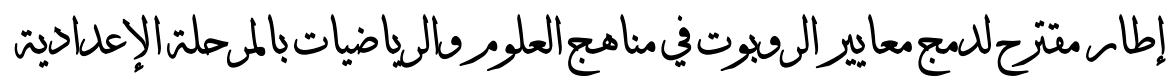

يُسهم في دمج المتعلمين في مفاهيم العلوم والرياضيات والهندسة والتكنولوجيا؛ لأن المتعلمين يكتسبون المهارات العلمية والهندسية لحل التحديات الروبوتية، وبالتالي تُريد من قدراتهم التحصيلية في المواد العلمية.

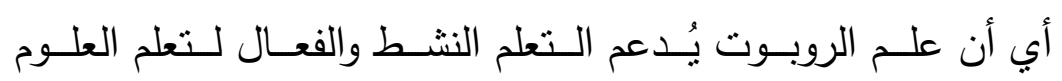

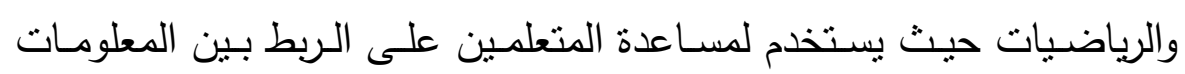

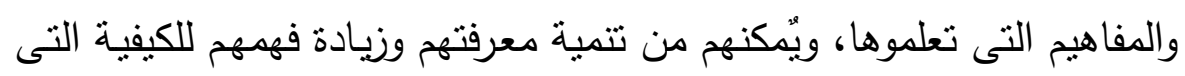

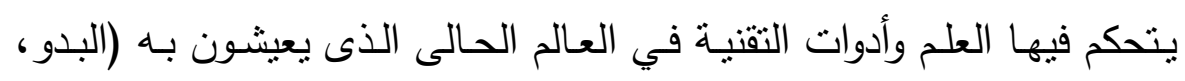

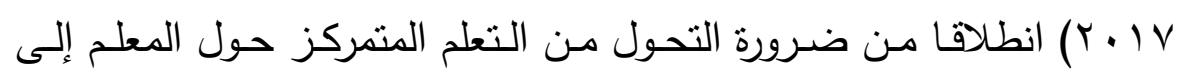

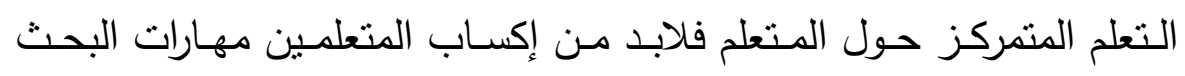

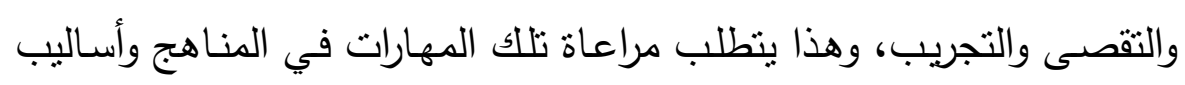
التنريس مما يتيح للطلاب فرص للتعلم الذاتى. وهن. ويمكن تصنيف طرق تعليم الرويوت من خلال طريقتين رئيسيتين هما: أولاً: توفير الروبوتات التعليمية الجاهزة للمتعلمين داخل صفوفهم بحيث

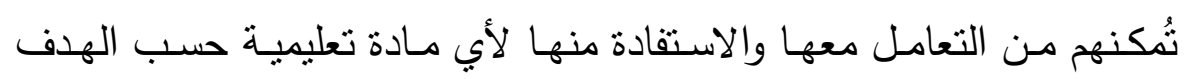

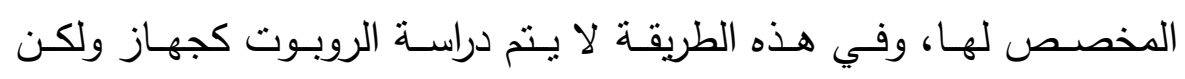

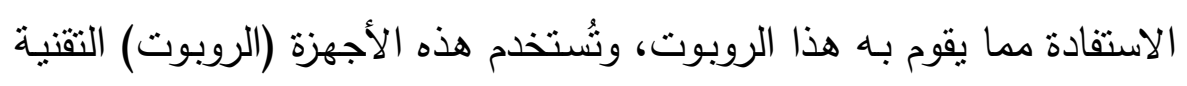

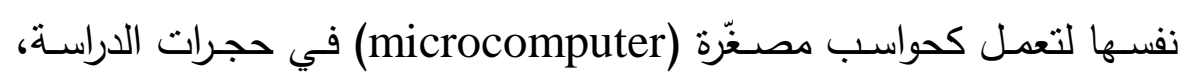
وتستطيع جميعها الاتصـال بـالكمبيوتز عن طريق منافذ خاصـة في جهاز

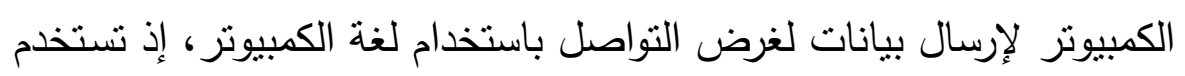
. $\leqslant r$. 


\section{المركن القومي للبحوث التبويةوالتنمية}

كل واحدةٍ منها لغة برمجة مختلفة، وتعتمد سـهولة البرمجة على لغة البرمجة المستخدمة، وهناك لغات برمجة مناسبة للمبرمجين المبتدئين، وعلى المُبرمج أن يقوم هو بتوجيه جميع أجهزة الروبوت إن أراد منها تتفيذ عدد أكبر من المهام، بعـد ذلك اسـتطاعت مجموعـة شـركات عالميـة مـن تصـميم حقائب وبرامج كمبيوتز مخصصة لإنتاج أجهزة الروبوت من صُنع المتعلمين بحيث يستطيع المتعلم تتفيذ مجموعة كبيرة من المشروعات الخاصـة به، وتمكن هذه الحقائب التعليمية المتعلمين من مختلف الأعمار من تصميم وبرمجة روبوتات

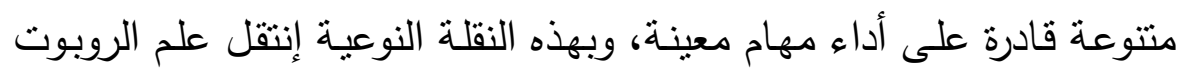
إلى المدارس بشكل فعلي حيث أصبح هنـالك إمكانيـة لتأسيس مختبرات أو معامل خاصسة بتعليم المتعلمين علوم الروبوت، وتمكنهم من تصميم أعداد

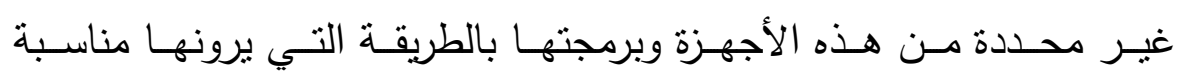

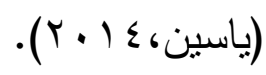

ثانيـاً: ويمكن تعليم الروبوت أيضـاً من خـلال توفير وتجهيز مختبر روبـوت تعليمسي بجميع الأدوات من (أسـلاكك ومواتير ، ومسنتـعرات ولوحسات الكترونية، وبطاريات وأزرار ، وتروس وعجلات وهياكل، ..الخ) داخل المعمل بحيث يتمكن المتعلمون من تعلم مفاهيم الروبوت ومهاراته ثُم التطبيق على ما تم تعلمـه في العلـوم والرياضـيات؛ لإنتاج روبوتـات قـادرة على أداء المهام المتتوعة وفق ما يتم برمجته عليه، ومع أهمية الطريقتين إلا أن الطريقة الثانية هي الطريقة الأفضل لما لها من نتائج أفضل مـع المتعلمين في تصميم وبناء 


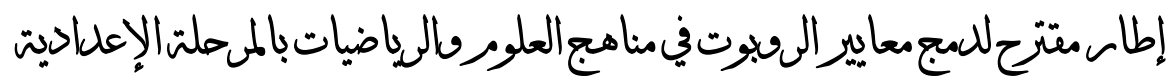

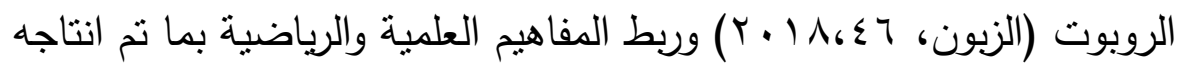
والتعرف على المشكلات التي تواجها وكيفية حلها.

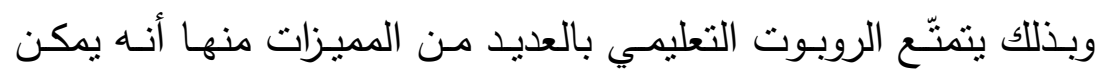

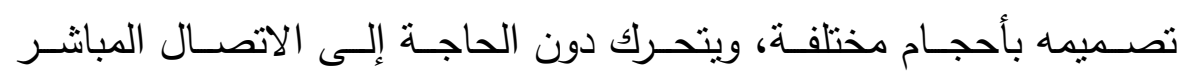

بالكمبيوتز ، كما أنها تستجيب للمتغيرات المحيطة وذلك باستخدام مستشعرات متتوعة، مثل: مستشعرات الضوء واللمس والصوت، كما بمكن برمجتها لأداء

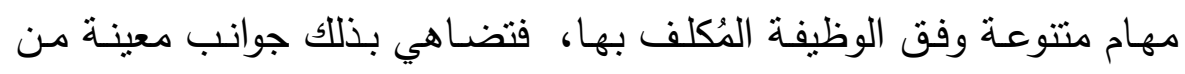
سلوكيات الإنسان. كما تُشهم الأنشطة المختلفة التى يمكن تنفيذها في تصميم

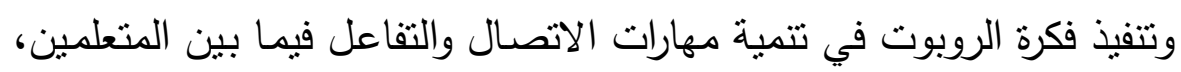

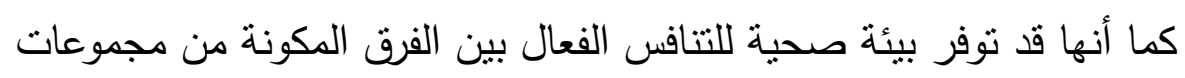
من المتعلمين. أهميـة علـم الرويـوت فـي تنميـة قـدرات المتعلمـين فـي مـادتي العــوم والرياضيات:

لما للروبوت من خصائص ومميزات تجعله مقبولاً ومرغوباً فقد لاقى

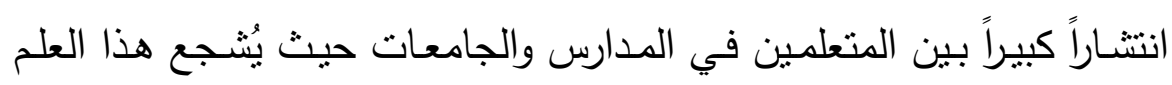

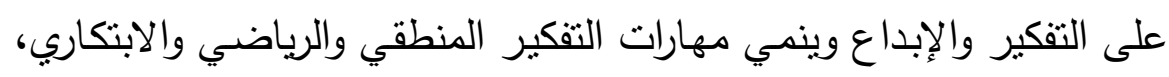
وكذلك يؤكد التربويون على أهمية التعليم من خلال تصميم وبناء وبرمجية الروبوت التى تستدعي روح التتافس في مسابقات الروبوت والابداع والتعلم

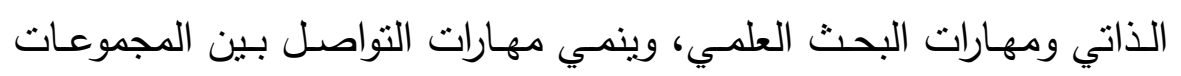

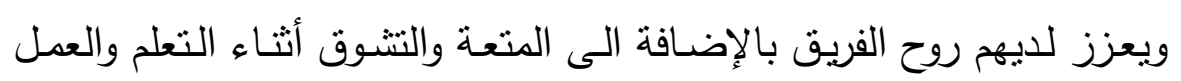
. $\leqslant$. البحث التربوي 


\section{المركن القومي للبحوث التبويةوالتنمية}

(Igor \& Eyal ,2003)؛ نظراً لبيئة التعلم التى تسود الفصل الدراسى في حالة تصميم وتتفيذ روبوت تعليمى والذى يتم من خلال فرق عمل جماعية

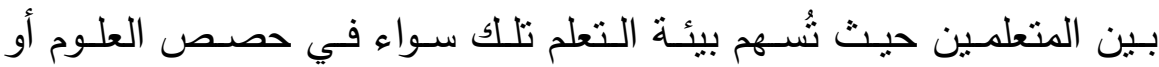
الرياضـيات في تتميـة قدرات المتعلمـين الابداعيـة وذلك مـن خـلال (عبد

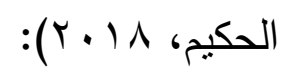

- - تشجيع المتعلمين على العمل ضمن فريق، والتعلم التعاونى. - ت تمية مهارات العمل البدوى. - تشجيع استراتيجيات التعلم القائم على المشروعات. - تـميـة وتعزيـز أنـواع التفكيـر المختلفــة الابداعيـة والناقـدة، وحـل المشكلات لدى المتعلمين. - تحفيز المتعلمين وحثهم على البحث العلمى لاكتساب مهارات الاستقصاء والملاحظة والتحليل. - - إطلاق الخيال العلمى والابداعى لدى المتعلمين. كما تسهم أنشطة الروبوت التعليمي في تعزيز أنماط التعلم البصرى والصوتى، وكذلك التعلم من خلال الحركة والممارسة اليدوية. كمـا أن علم الروبوت يُمثنل وسيلة تعليميـة تحقق العديد مـن الفوائد ويسمح بتطبيق العديد من النظريات التربوية الحديثة التى ينادى بها الخبراء، والتي أثنتت الدراسات جدواها وأهميتها في العملية التعليمية(عمير، 7 ( • ب). وقد لوحظ أنه في جميع المداخل السـابقة يتم تطبيق مفاهيم الفيزباء والرياضـيات والعلـوم والتكنولوجيـا مـن خـلال الروبـوت، حيـث تسـاعد على 


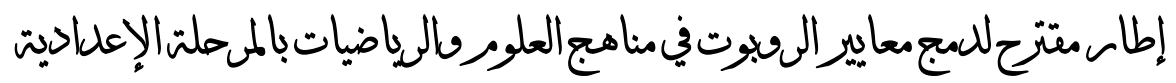

تحسـين التربيـة العلميــة لأن المتعلمـون يثــنركون فـي عمليـات البنـاء

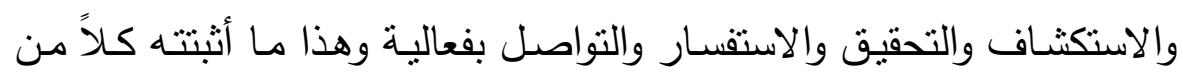
الدراسات النالية: Giannakopoulos, 2009; Pedaste \& Sarapuu) 2006; Pedaste, Maeots, Leijen, \& Sarapuu,2012) ففي العلوم: يجري تجربة السرعة، واستكثاف تأثثر الاحتكاك، وتجربة

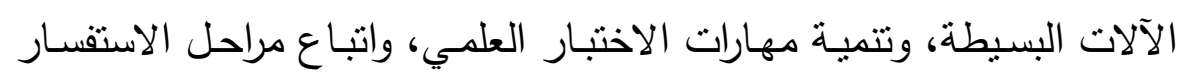

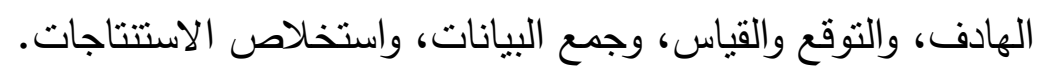

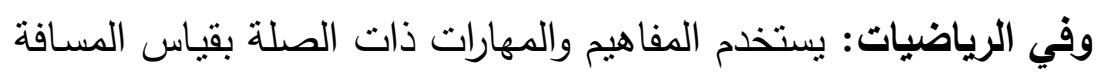

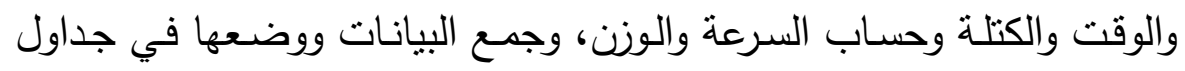
وتفسيرها وحساب النسب بشكل غير رسمي(Mindstorms, 2011 Lego) فضلاً عن التعاون وحل المشكلات وتوظيف مهارات التواصل كأحد العمليات الرياضية.

وفي التكنولوجيـا: يُحدد المكونـات التقنية لإنشـاء نمـاذج عمل ثلاثيـة

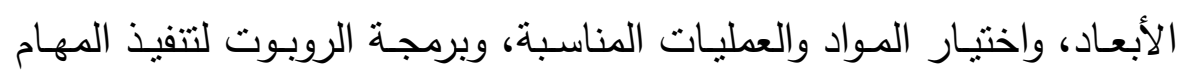
المطلوبة.

وفي الهندسـة: يستخدم عمليـة التصـيم الهندسي لتجربـة المتغيـرات

وتقييمها.

كيف يمكن الاستفادة من علوم الرويوت في العملية التعليمية:

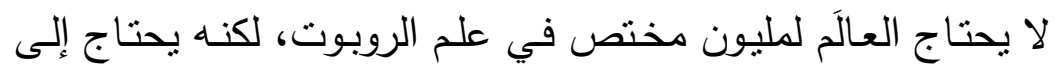

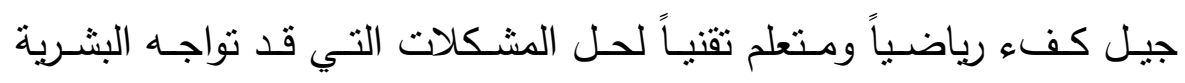




\section{المركن القومي للبحوث التبويةوالتنمية}

مستقبلاً، لهذا يجب الاتفاق على أن تدريس علم الروبوت يهدف إلى مساعدة المتعلمين على فهم متغيرات الثورة المعرفية والعالم الرقمي الذي ينتمون إليه، وكيفية التكيف مـع المستجدات والمعوقات التى تحول دون تحقيقهم للأهداف المرجوة، وهذا يؤكد على أن دمج علم الروبوت كأحد التقنيات الحديثة يحقق العديد من المميزات منها:

محو الأمية التكنولوجية لاى المتعلمين.

الإعداد الجيد للمجتمع الرقمي.

نشر ثقافة التعلم والبحث وجعلها منهج حياة.

(American القضـاء على الرهبة من المجالات العلميـة

Society for Engineering Education, 2013)

وبذلك يُعد الروبوت أحد المجالات الحديثة التي تحقق انتشـارًا

سريعًا وواسعًا في الأوساط التعليمية في أنحاء كثيرة من العالم، فالروبوت كأداة تتفيذ للمهام يمال زوايا حياتتا وبقوم بالكثير من الأعمال التي يعتبر بعضـها مستحيلًا بالنسبة للإنسـان، وتصميم وتركيب روبوت يبدأ من

مبـادىء بسـيطة يتعلمها المـتعلم ويقوم بالاسـتفادة منهـا كمدخل لتتعلم المبادىء الأساسية في العلوم والرياضيات من خـلال هذا التطبيق أو ذاك.

وفي دراسـة حالة قام بها إيجور وإييال (Igor \& Eyal والتـي تتعلـق بتصـميم الروبـوت الخـاص بإطفـاء الحرائـق وتقيـيم مخرجاتـهـ التعليمية والذي يهذف الى تعلم المتعلم مهارات التصميم والتقنية، حيث يحتاج المـتعلم للعمـل ضـمن فريـق لتنفيذ فكرة معينـة للروبـوت ممـا بطـور مهارات .$\Sigma V$. 


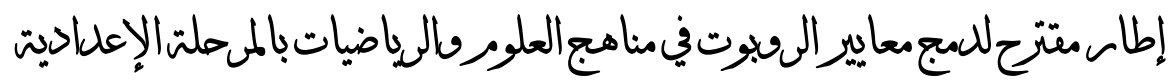

الاتصـال والتفاعل بين المتعلمين، كما أن الطرق المختلفة والممكنة لإنجاز

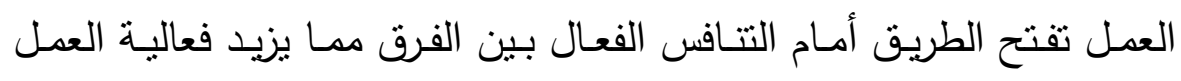

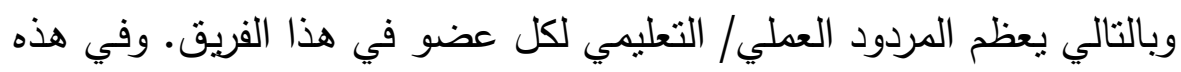
الدراسة مارس المتعلمون التصميم التكاملي وصمموا نظام ميكانيكي وتمكنوا

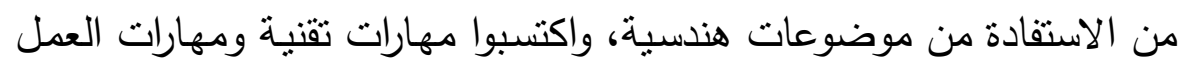

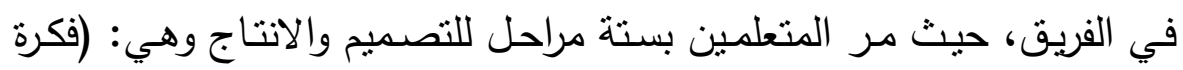

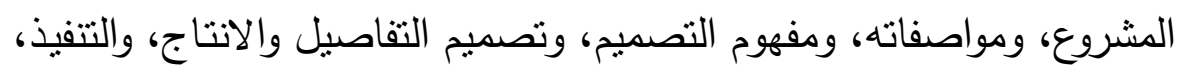

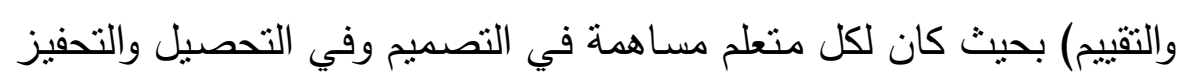
واتجاه نحو التقنية.

وعليه فإن علم الروبوت هو المتمّم الأول للتعليم في عصرنا الحديث،

حيث يمكن استخدامه لتطبيق وتوظيف المعارف النظرية المجردة والتى منها: (عرض المميزات الميكانيكية وتحويل الوحدات، والنسبة والتتاسب والتصميم

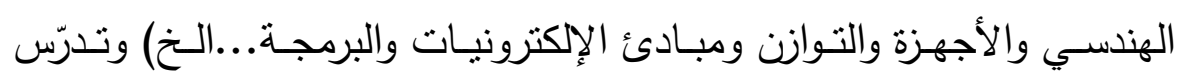

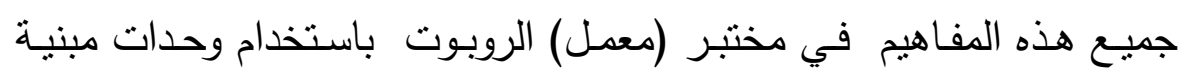

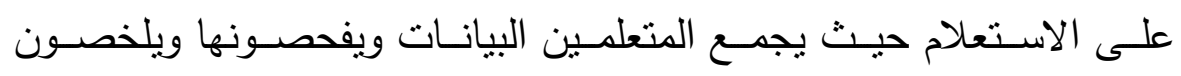

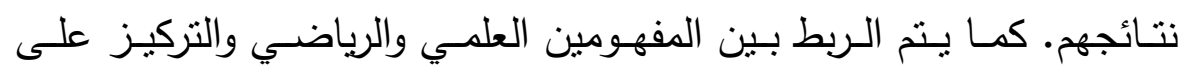

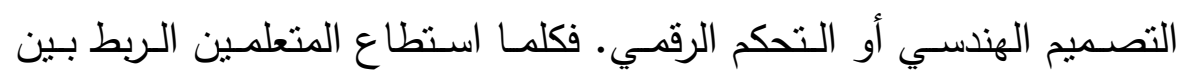

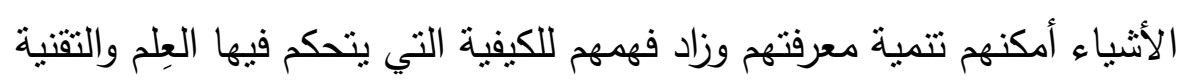

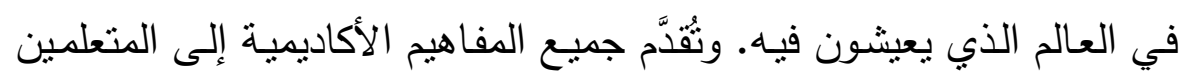

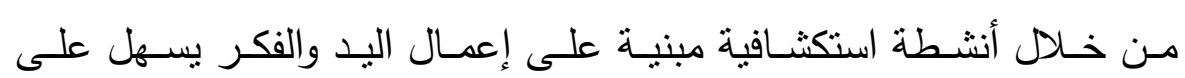
. $\leqslant$. 


\section{المركن القومي للبحوث التبويةوالتنمية}

المتعلمين فههها، ليس هذا فقط بل أيضًا لمواكبة معطيات العصر في امتلاك المهارات اللزمة لدخول مجالات التكنولوجيا الحديثة والتي أصبح الكمبيوتز ركنًا رئيسًا ومفتاحًا ضروريًا للاخول إليها (سعادة والسرطاوي، ب. . ب؟ الحدابي

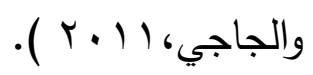

وبذلك تحقق أنشطة الروبوت ما يلي:

- مشاركة المتعلمين في أنشطة تُكسبهم مهارات التقصى.

- - استخدام التقنيات والتجهيزات الحديثة والمثقدمة أثناء تتفيذ الأنثطة. - - تدريب المتعلمين على فنيات استخدام التكنولوجيا والبرمجـة لتصـيم

$$
\text { وتتفيذ وتيسيرعمل الروبوت. }
$$

- تدعيم وتتمية مهارات المتعلمين السـابقة والبناء عليها خطوة بخطوة؛

$$
\text { لتوظيف مفاهيم ومهارات العلوم والرياضيات. }
$$

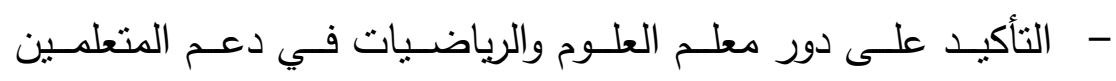
ومسـاعدتهم على تحقيق الهدف والفهم العميق لمهارات الروبوت من خـلال تــوع الأنشــة والأسـئلة المفتوحـة، وتشــيعهم على التفكيـر

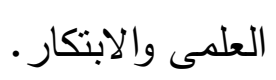

ومسع تتوع الروبوت وفقًا للمهام التى يقوم بها يجب أن تنتوع المداخل

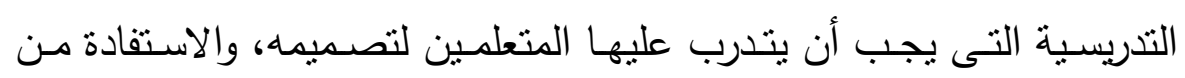
مفاهيمه ومهاراته ومن هذه المداخل: > التعلم بالاكتشاف. > التعلم التعاوني. 


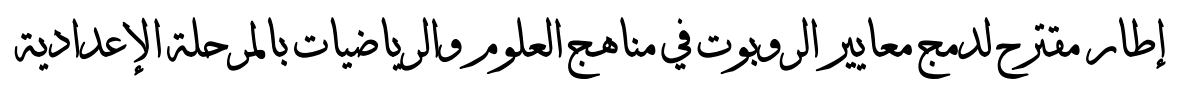

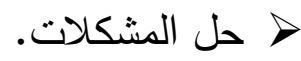

> التعلم القائم على المشروع. > التعلم القائم على المنافسة.

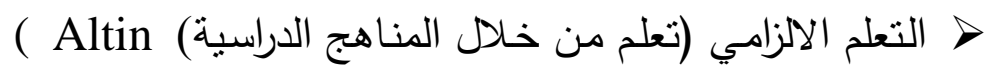

.\&Pedaste, 2013).

وقد تم تضمين تعليم الروبوت في العديد من مدارس العالم حيث لاقى

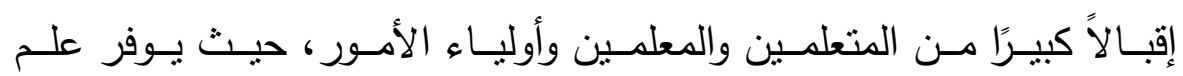

الروبوت البيئة المشتجعة والمبنيـة على التعلم الذاتي والعمل اليدوي، ودمهج

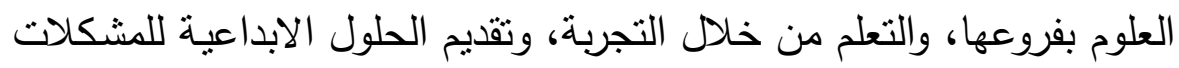

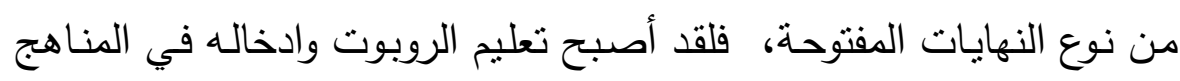
واحداً من أولويات المدارس العصرية الحديثة المواكبة والمشجعة للتكنولوجيا لتوبيا

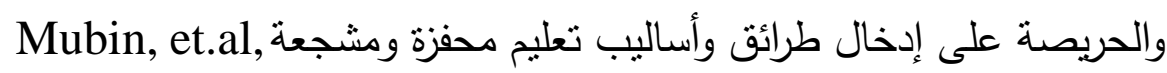

(2013)

ولقد أكدت على ذلك دراسة (البدو، Y V Y Y) عندما سعت إلى معرفة

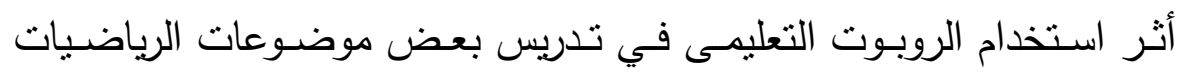

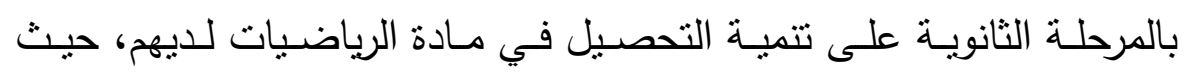
تكونت عينة الدراسة من (• ب) طالبة، وتم دراسة موضوع الاتصال والاشتقاق

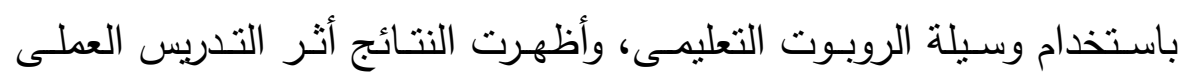

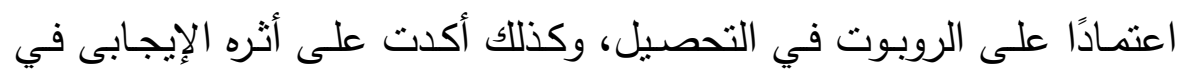

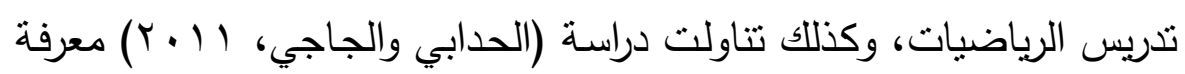
.0. 


\section{المركن القومي للبحوث التبويةوالتنمية}

أثز التدريب في بناء وبرمجة الروبوت على تتمية مهارات التفكير الإبداعي ومهارات التفكير العلمي لـدى عينـة مـن الطـلاب الموهـوبين بإجمـالي( • ؟) ساعة تدربيية، حيث أثبتت الدراسة فعالية التذربب بالروبوت في تتمية مهارات التفكير العلمي ومهارات التفكير الإبداعي. ولتعـديل المـنهج وإدخـال الروبـوت ومفاهيمـه ضــن المحتـوى فهذا يتطلب تضمين المنهج محتوى خاص بعلم الروبوت في تعليم المواد الدراسية المختلفة، مثل: العلوم والرياضيات والتى ثُسهم في توضيح وتفسير المعارف والمهـارات المرتبطـة بـالروبوت، ويلـى ذلك تجهيـز مجموعـة مـن الحقائـب التدربيية والبرامج الخاصة بتصميم الروبوت وبرمجتة وتشغيله ، ثم عقد برامج تدريبية تتضمن (العبري، ( • ب): - تفعيـل مفـاهيم الرياضـيات والهندسـة مـن خـلال أنثـطة تصـميحم روبوت بأشكال مخنلفة.

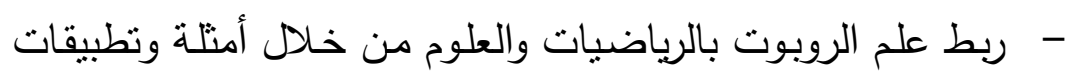
حياتية.

- - تفعيـل آليـات ربط العلـوم والرياضـيات بيئـة مشـجعة مـن خـلال عرض حلول للمشكلات، والعلوم المختلفة بمشروعات عملية. وقد عاب بعض التربوبين أن يُستخدم علم الروبوت كوسيلة للتسلية والمتعـة، وذلك لأن تدربس علم الروبـوت بُمثنل بوابـة الاختراعـات في كل مجالات الحياة، وأنه سيُمكنهم من اكتساب العديد من المهارات (بوعصبانة،

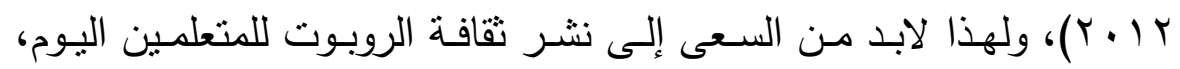




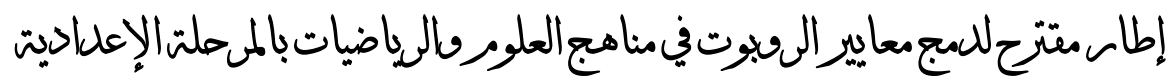

وحيث أن المعايير هي الموجه الأساس لعملية التعليم والتعلم، سيتم فيما يلي استعراض الأُسس التي يجب أن تُبنى عليها هذه المعايير . أُسس ومعايير تعليم الرويوت في المدارس:

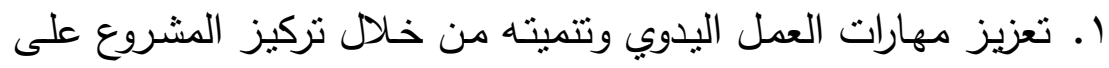

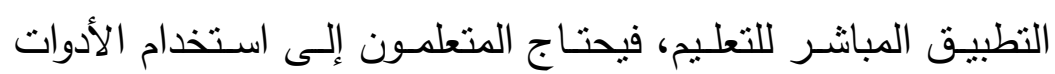

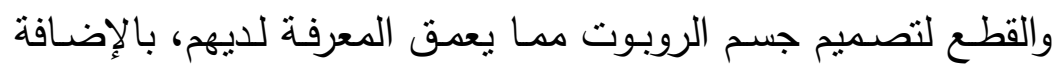

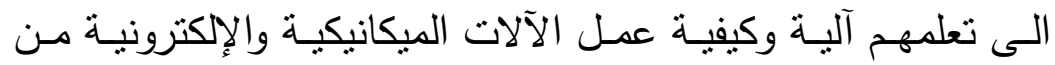
خلال ممارساتهم الفعلية لتركيب الآلات المختلفة.

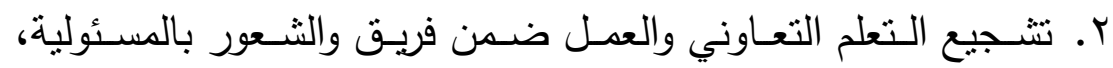
وتتمية المهارات القيادية عبر توزيع أدوار مختلفة على المتعلمين.

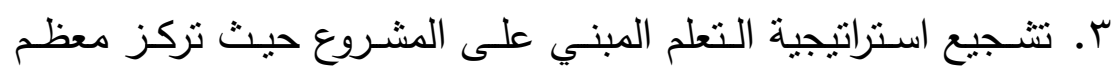

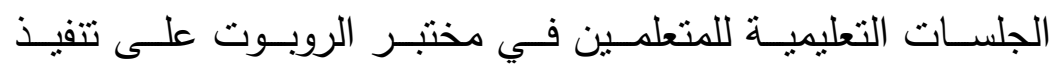
المتعلمون لمشروع ما، منل : (إنتاج سيارة تسير بشكل معين، تصميم انسان آلي، تصميم روبوت قادر على إجراء تجارب كيميائية...الخ)

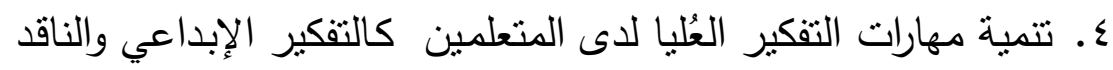
والانفعالي والذكاءات المتعددة، بالإضافة الى مهارات حل المشكلات.

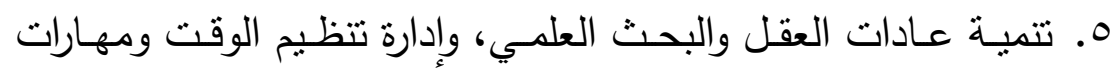
التحليل وإدارة المشروع مما يدفعهم نحو الابتكار والابداع في التصميم والبرمجة، ومعالجة التحديات من خبراتهم التي يتعلموها. 


\section{المركن القومي للبحوث التبويةوالتنمية}

7 ـ تحقيق مفهوم التكامل بين مفاهيم العلوم المختلفة (كالحركة والسرعة

و....الخ) ومفاهيم الرياضيات والإلكترونيات والبرمجة مما يُسهم في

تقديم فهم متكامل للعلوم، وتمكين المتعلمين واعطائهم فكرة عملية عن

كيفية دمـج العلوم المعرفية والانسانية والعلمية في سبيل انتاج منتج

علمي.

V. تشجيع التعلم الذاتي لاى المتعلمين من خلال اشتراكهم في مشروعات

تعتمد على معرفتهم السـابقة ومـا يحصلون عليه من مصسادر متوفرة

بين أيديهم، حيث يتطلب تعليم الروبوت من المتعلم الحصول على يلى

الحد الأدنى من التعليم والحد الأعلى من التعلم.

^. يربط التعلم بالحياة العملية لأن أغلب المشروعات والتطبيقات التربوبة التية

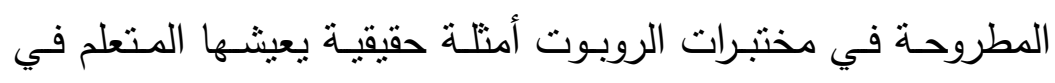

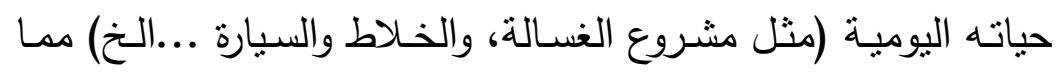

يجعل المتعلم يتعلم أكثر من خلال فهمه وتطبيقه لآلية عمل الآلات

والأجهزة التي يستخدمها يومياً ويربطها مع ما يتم تعلمه أثناء تواجده

$$
\text { في مختبر الروبوت (الهباهبة، • 1 • ( ). }
$$

ومما سبق يتضح أهمبة حاجة المتعلم إلى اكتساب مفاهيم الروبوت ومهاراته من خـلال تضمين معايير الروبوت في كل من مـادتي العلوم والرياضبات، وذلك لتتمية تلك المفاهيم لدى المتعلمين بمحتوى مناسب مع توظيف مفاهيم العلوم والرياضيات، والإهتمام بالأنشطة التعليمية للربط بين المعرفة النظريـة المجردة والتطبيقات الحياتية المتمتلة في تطبيقات الروبوت. 


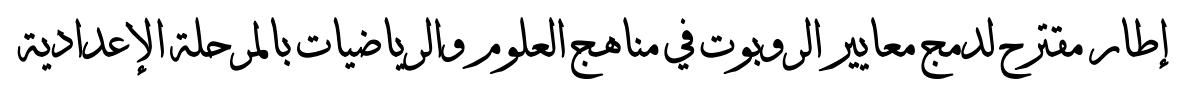

\section{الطريقة والاجراءات:}

هنهج الدراسة:

أولاً: المنهج الوصفي: وذللك لتحديد معايير الروبوت والتي يجب أن

تتكامل مع مناهج العلوم والرياضيات.

ثانياً: أسلوب دلفاي: بمراجعة الدراسات السابقة التي اهتمت بتكامل المفاهيم مع معايير المنهج عموماً ومفاهيم الروبوت خاصةًً، وجد أنها

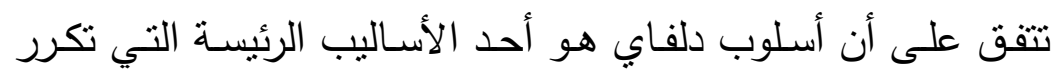

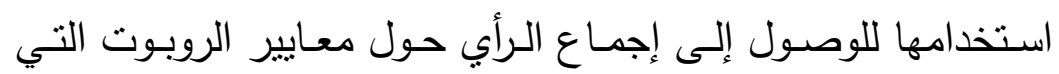
يجب أن تتكامل مع مناهج العلوم والرياضيات.

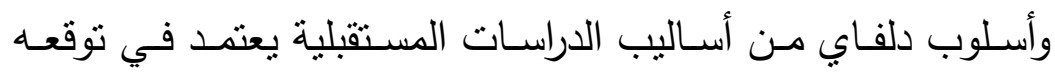

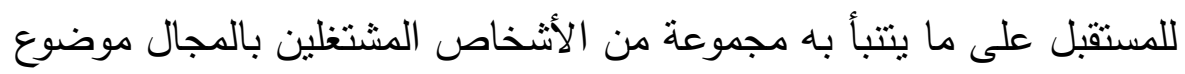

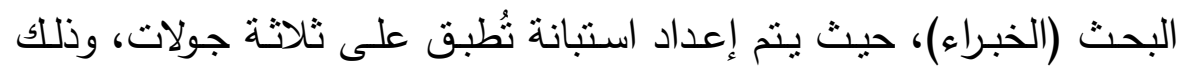

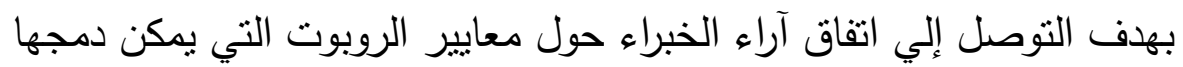

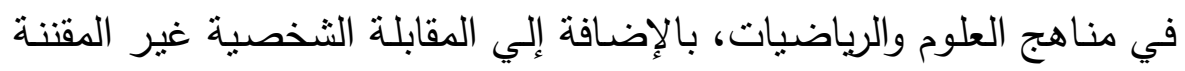
مع بعض الخبراء بعد تطبيق الجولتين الأولي والثانية من جولات دلفاي.

\section{خطوات الدراسة واجراءاتها:}

أولاً: تحديد معايير الرويوت التي يمكن دمجها في مناهج العلوم والرياضيات بالمرحلة الاعدادية، وقد نم ذلك من خلال :

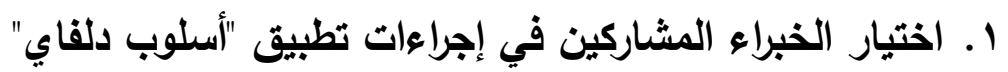

$.0 \leqslant$. 
تم اختبار عدد مـن المتخصصسين لإجراء التجربـة الميدانيـة للاراسـة وفق عدد مـن المعـيير منهـا أن يكـون لـه خبـرة في مجـال تدريس مفـاهيم الروبـوت والتـدريب على مهاراتـه، وأن يكون متخصصـاً في مجـال التربيـة العلمية عموماً، ولديـه اهتمامات بتكنولوجيا الروبوت، وأن يكون له خبرة في

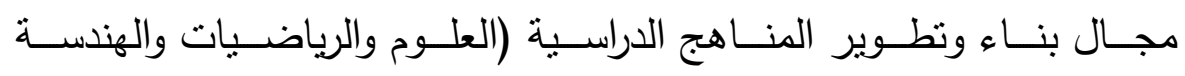
والتكنولوجيا)، بالإضافة الى عدد من المعلمين والموجهين المسئولين عن تتفيذ منـاهج العلوم والرياضيات، ومسن خـلال المقابلة الشخصية تم اختيـار (ع (؟) خبيـر للمشـاركة في التجربـة الميدانيـة للاراسـة، وكانـت العينـة موزعـة طبقاً للتخصص كما يلي:

\section{جدول (1)}

توزيع الخبراء والمحكمين في الدراسة

\begin{tabular}{|c|c|c|c|}
\hline معلمين وموجهين & باحثين في هندسة & تذريس علوم وطرق & التخصص \\
\hline$\Lambda$ & 7 & 1. & عدد الخبراء \\
\hline
\end{tabular}

r. الجولـة الأولى لدلفاي: وتهدف إلى الوصول إلى إجماع المشـاركين حـول معـايير الروبـوت التـي يمكـن دمجهـا فـي منـاهج العــوم والرياضـيات بالمرحلـة الاعداديـة، بحيث اتبعت الباحثتان الخطوات 


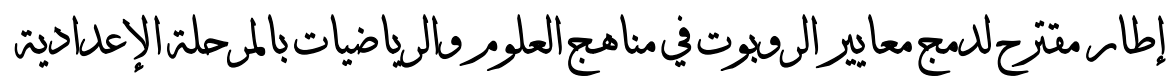

بناء الإستبيان : نم بناء الإستبيان الذي استخدم في جولات

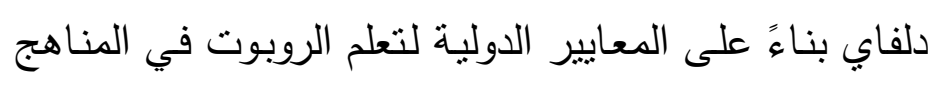

الدراسية وذلك من خلال الخطوات التالية:

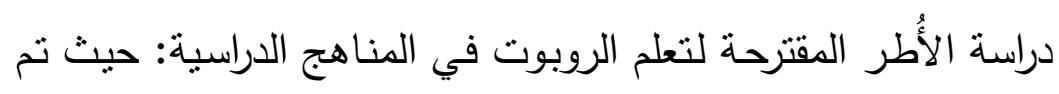

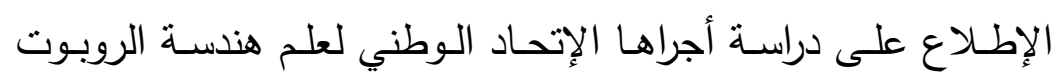

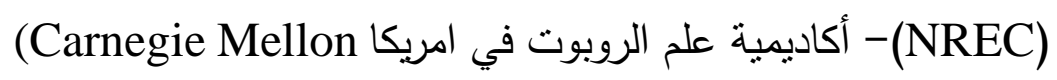
Robotics Academy ,2017) والذي قام بدراسة المواصفات القياسية الوطنية للعلوم في أمريكا بالإضافة إلى المواصفات القياسية

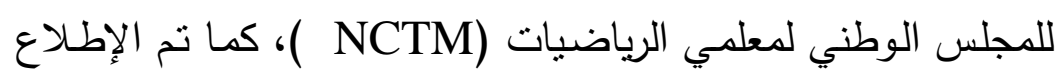

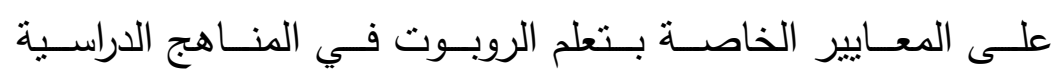
(Robotics Education Symposium Science, Technology, Engineering, \&Mathematics ,2006)

$$
\text { شارك في وضعها كلاً من الهيئات الآتية: }
$$

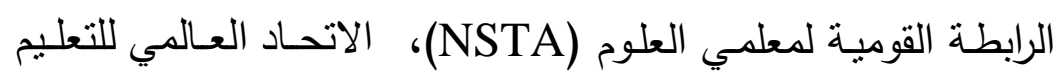

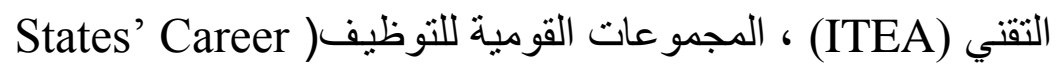

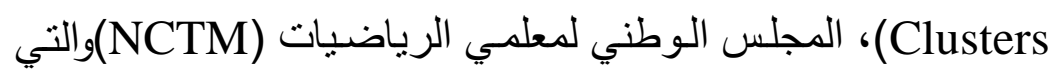

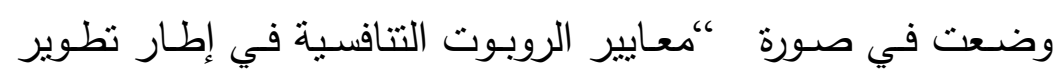

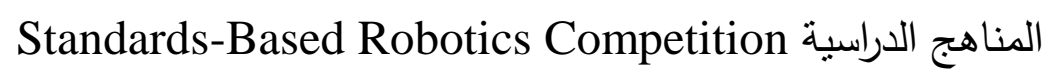
Curriculum Development Framework" فحص كل من الدراسات التي اهتمت بمعايير الروبوت وكذلك العديد بالإله 


\section{المركن القومي للبحوث التبويةوالتنمية}

مـن الأبحـاث التـي تتاولتهـا بالوصـف والتحليـل، وعليـه فلقد تبنـت الدراسة الحالية المعايير الدولية في الروبوت في إطار تطوير المناهج الدراسـية؛ لإعـداد قائمسة معـايير يمكن دمجهـا في منـاهج العلـوم والرياضيات بالمرحلة الاعدادية.

إعـداد الصــورة الأوليـة للإسـتبيان: بتحليـل المعـايير الدوليـة في الروبـوت مـن المصـادر السـابق عرضـها، تم بنـاء الإسـتبيان الذي إني تضمن أربع مجالات هى: (مجال الأمن - المجال المفاهيمى لكل من العلوم والرياضيات- مجال الأداء-مجال العمل المشترك "المجال التكاملى")، ويتبع كل مجال عددًا من المعايير ، ويتبع كل معيار عدد من المؤشرات وذلك من خلال مقياس ثنائي يوضح مدى مناسبة تلك المفردات (أوافق - لا أوافق) ومساحة لإضافة أي تعديلات مقترحة. صـدق الإسـتبيان : تم عرض الإستبيان في صسورته الأوليـة علي لإني مجموعـة من المحكمين، للتعرف على أرائهم في عبارات الإستبيان والتحقـق مـن صـدق المحتـوي ومـدي سـلامة المفـردات وارتباطهـا بالمجـالات والمعـايير والمؤشـرات الخاصـة بكـل مجـال، وتـم تعـديل الإستبيان ستبيان في ضوء ملاحظات السادة المحكمين. ثبات الإستبيان : لحساب ثبات الاستبيان تم تطبيقه على عينه دن خبراء المناهج، وتم حساب الثبات باستخدام معادلة ألفاكرونباخ حيث بلغــت قيمـة معامـل الثبـات (^9, • ) وهـي قيمـة تـدل على ثبـات الإستبيان وصلاحيته للتطبيق. 


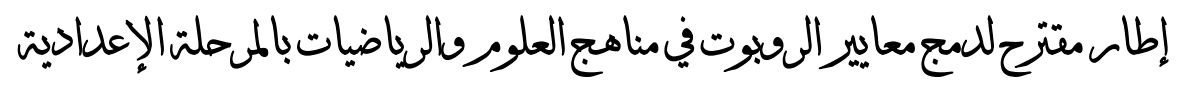

الصـورة النهائيـة للإسـتبيان: تمثلت الصـورة النهائيـة للإسـتبيان في الأربعة مجالات الرئيسة الحالية، ويتبع كل مجال عدداً من المعايير

والمؤشرات (ملحق ())، كما يوضحه الجدول الآتي:

جدول (r)

يوضح عدد المعايير والمؤشرات الخاصة بكل مجال بالجولة الأولى

لالفاي

\begin{tabular}{|c|c|c|}
\hline المؤشرات & المعايير & المجال \\
\hline$\wedge$ & 1 - أساسيات السلامة & \multirow{3}{*}{ 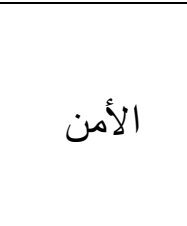 } \\
\hline 7 & r- متطلبات السلامة & \\
\hline$\checkmark$ & r- ارشادات الأمن والسلامة & \\
\hline rv & 1- في العلوم & \multirow{2}{*}{ المجال الميمى } \\
\hline rv & r - في الرياضيات & \\
\hline$r$. & 1- التصميم & \multirow{3}{*}{ 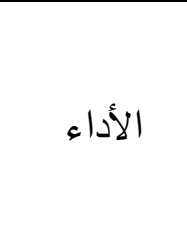 } \\
\hline 10 & r- بناء المنتج وصبانته. & \\
\hline 1. & r- مراجعة الأداء (التقييم) & \\
\hline$r \cdot$ & 1- العلوم والممارسات الهندسية & \multirow{3}{*}{ المجال العمل } \\
\hline 1. & r- إدارة العمل والتتظيم & \\
\hline 1. & r- الاتصال والتواصل & \\
\hline
\end{tabular}

.01.

البحث التريوي 


\section{المركن القومي للبحوث التبويةوالتنمية}

\begin{tabular}{|c|c|c|}
\hline المجال & \\
\hline $1 \Lambda$ & المؤشرات & \\
\hline
\end{tabular}

تطبيق الصورة الأولى للإستبيان: تم عرض الإستبيان على الخبراء

المشاركين وذلك في مقابلة شخصية للإتفاق على المعايير والمؤشرات الخاصة بالروبوت في مناهج العلوم والرياضيات بالمرحلة الإعدادية. وكان من أهم نتائج الجولة الاولى لالفاى :

دمج معياري أساسيات السلامة مع إرشادات الأمن والسلامة في مجال الأمن وليصبحا معيارًا واحدًا وهو أساسيات الأمن والسامة، مع إعادة صياغة بعض المؤشرات وفق كل معيار • بالنسبة للمجال المفاهيمي والخاص بمعايير العلوم والرياضيات اتفق السادة المحكمون على أهمية الفصل بينهما، ووجود معايير خاصة بالعلوم وأخرى للرياضيات مع التأكيد على التكامل فيما بينهما عند تنفيذ الأنشطة وعمليات التعليم والتعلم. دمج المجال الثالث(الأداء) والمجال الرابع (مجال العمل المشترك الثك "المجال التكاملي") ليكونا مجالًا واحدًا وهو (مجال الأداء "التصميم والتنفيذ والتقويم" ) بحيث يشمل هذا المجال مؤشرات كل منهما. في ضوء عملية الدمج تم إعادة دمج وصياغة بعض المعايير ، وكذللك بعض المؤشرات ليكون عدد المؤشرات في نتائج الجولة الأولى (ع إ) بدالًا من (1) (1). 


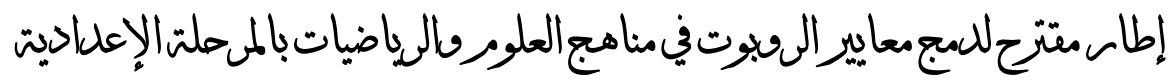

r.الجولة الثانية لالفاي: وتهدف للوصول إلى إجماع المشاركين حول قائمة

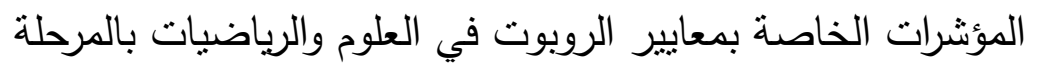
الإعدادية.

إعداد الصورة الثانية من الإستبيان : أجريت التعديلات المتفق

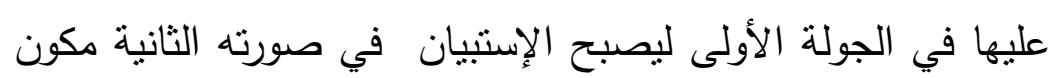

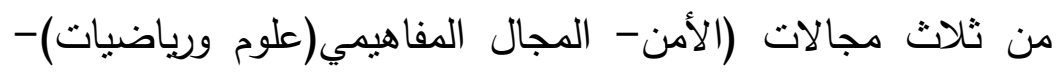

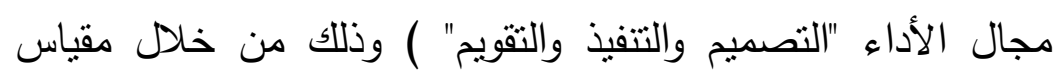

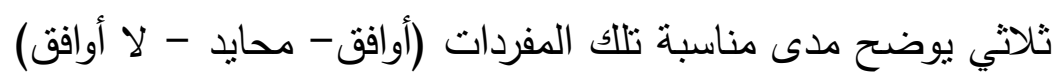

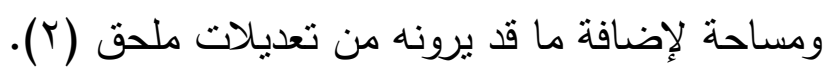

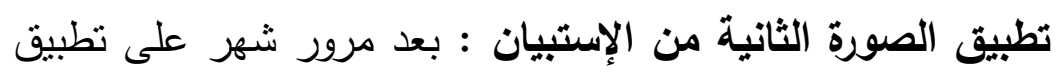

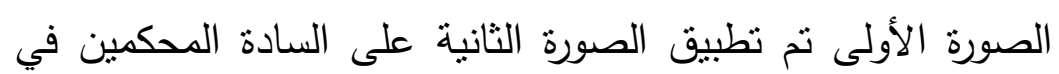

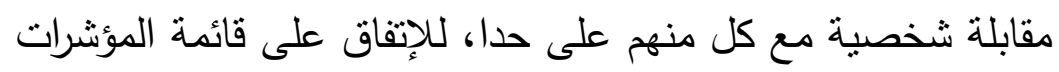

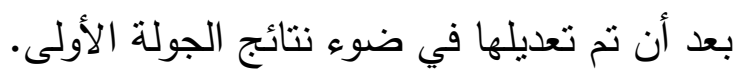
تحليل نتائج الإستبيان : تم تحليل استجابات المشاركين في الجولة فئلة

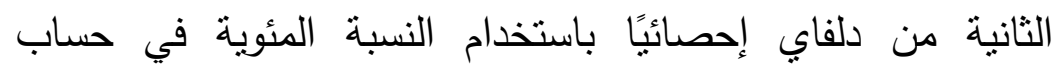
التكرارات لكل مفردة من مفردات الإستبيان؛ لتحديد مستوى الموافقة في كل عبارة تتضمن استجابات من ثلاث درجات وذللك بتطبيق المعادلة الآتية: النسبة المئوية $=$ .7. البحث التربوي 
وأخذت الدراسة بالقيمة التي تجاوزت نسبة الاتفاق عليها V \%

كحد الكفاية كمجموع للتكرارات التي تجمع بين الموافق والمحايد في قبول

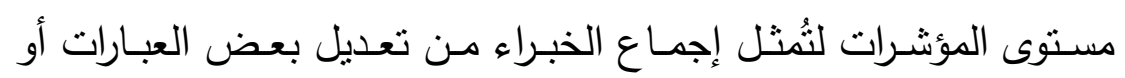
حذفها، والجدول الآتي يوضـح نتـائج الجولـة الثانبـة بعـد ادخـال كافـة الملاحظات من التعديلات المطلوبة.

\section{جدول (r)}

يوضح عدد المؤشرات الخاصة بكل مجال بعد الجولة الثانية لالفاي

\begin{tabular}{|c|c|c|}
\hline المؤشرات & المعاييز & 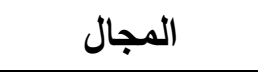 \\
\hline 9 & 1 - أساسيات الأمن والسلامة & \multirow{2}{*}{ 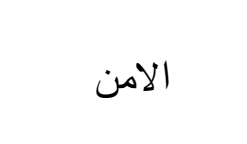 } \\
\hline 0 & r- متطلبات السلامة & \\
\hline re & 1- 1- في العلوم & \multirow{2}{*}{ المجال المفاهيمى } \\
\hline 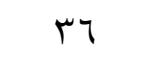 & r- في الرياضيات & \\
\hline 17 & 1 - التصميم & \multirow{5}{*}{$\begin{array}{c}\text { (التصميم - الاداء } \\
\text { - التفيذ- التقويم) }\end{array}$} \\
\hline$\wedge$ & ץ- بناء المنتج وصيانته. & \\
\hline r & r- مراجعة الأداء (التقييم) & \\
\hline 0 & ع - إدارة العمل والتتظيم. & \\
\hline 0 & 0- الاتصال والتواصل & \\
\hline 119 & المجموع & \\
\hline
\end{tabular}

ع الجولة الثالثة لالفاي: وتهدف للوصول إلى اتفاق المشاركين على القائمة

النهائية للمؤشرات التي يُمكن دمجها في مناهج العلوم والرياضيات بالمرحلة الإعدادية، وقد تمت من خلال الخطوات الآتية: 


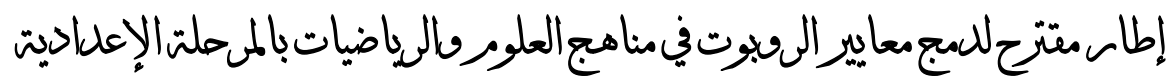

صياغة العبارات: بناء على ما تم الاتفاق عليه في الجولتنين الأولى والثانية، تم تعديل صياغة وحذف عدد من المؤشرات في كل معيار فرعي مرتبط بالمجالات للوصول إلى الصورة النهائية والموضحة في في فئي ملحق(r).

تطبيق الإستبيان : بعد مرور شـهر على الجولة الثانية تم عرض

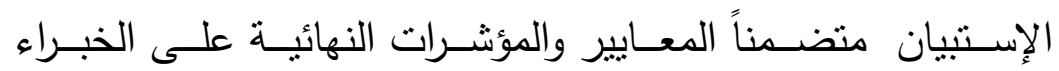
المشاركين في مقابلة لإبداء الرأي حول امكانية دمج معايير الروبوت ولئان اجرائياً في مناهج العلوم والرياضيات بالمرحلة الإعدادية.

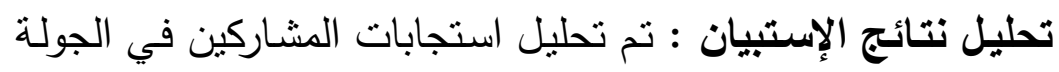

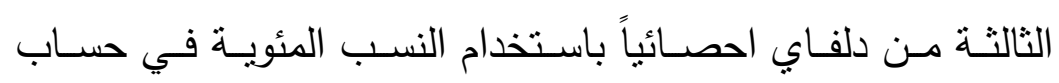

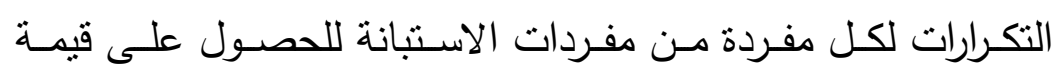
المتوسط، والجدول التالي يوضح نتائج الجولة الثالثة بعد ادخال كافة لئة الملاحظات والتعديلات المطلوبة التي يمكن دمجها في مناهج العلوم والرياضيات بالمرحلة الإعدادية.

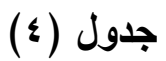

يوضح عدد المعايير والمؤشرات الخاصة بكل مجال بالجولة الثانية لدلفاي

\begin{tabular}{|c|c|c|}
\hline المؤثرات & المعايير & المجال \\
\hline \multirow{2}{*}{$v$} & 1- أساسيات الأمن & \multirow{3}{*}{ الامن } \\
\hline & والسلامة & \\
\hline 。 & ץ- منطلبات السلامة & \\
\hline
\end{tabular}

$.7 r$.

البحث التربوي 
المركن القومي للبحوث التبويةوالتنمية

\begin{tabular}{|c|c|c|}
\hline المؤشرات & المعايير & المجال \\
\hline r & 1- في العلوم & \multirow{2}{*}{ المجال هيمى } \\
\hline r & r- في الرياضيات & \\
\hline 11 & 1- التصميم & \multirow{5}{*}{ 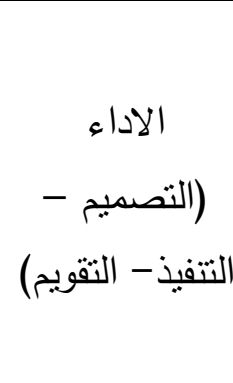 } \\
\hline$\wedge$ & r- بناء المنتج وصيانته. & \\
\hline 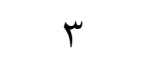 & r- مراجعة الأداء (التقييم) & \\
\hline$\varepsilon$ & ع- إدارة العمل والتتظيم. & \\
\hline$\varepsilon$ & 0- الاتصال والتواصل & \\
\hline 1.7 & المجموع & \\
\hline
\end{tabular}

بانتهـاء الجولـة الثالثـة مـن جـولات دلفـاى واجــراء كافـة التعـديلات الته والوصول إلى القائمة النهائية بمعايير ومؤشرات الروبوت (ملحق ع)، والتى يمكن دمجها في مناهج العلوم والرياضيات بالمرحلة الاعدادية تكون قد تمت

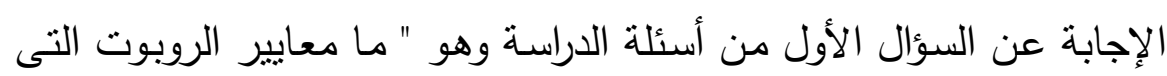
يمكن دمجها في مناهج العوم والرياضيات بالمرحلة الإعدادية؟" ثانياً: للإجابة عن السؤال الثاني: ما التصور المقترح لامج معايير الرويوت في مناهج العلوم والرياضيات بالمرحلة الإعدادية ؟ باستخدام قائمة معايير ومؤشرات الروبوت الناتجة عن الجولات الثناث لدلفاي (ملحقء) وبعد إجراء تعديلات السادة المحكمين، تم إعداد تصور لمصفوفة المعايير والمؤثرات لمعايير الروبوت والتي يمكن دمجها في مناهج العلوم والرياضيات بالمرحلة الإعدادية، حيث أصبحت المصفوفة في صورتها النهائية تتناول معايير ومؤشرات تم توزيعها بشكل متتابع بين الصفوف .74. 


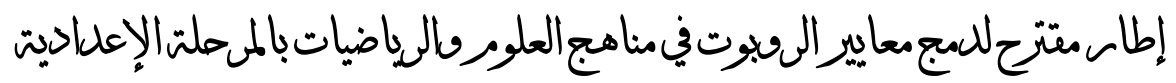

المختلفة لكل صف دراسي بالمرحلة الإعدادية كما هو موضح في الجدول الآتي:

جدول (•)

يوضح توزيع مؤشرات الرويوت فى العلوم والرياضيات على الصفوف الثلاثة

بالمرحلة الاعدادية

\begin{tabular}{|c|c|c|c|c|}
\hline الثالث & الثانى & الأول & المعيار & المجال \\
\hline 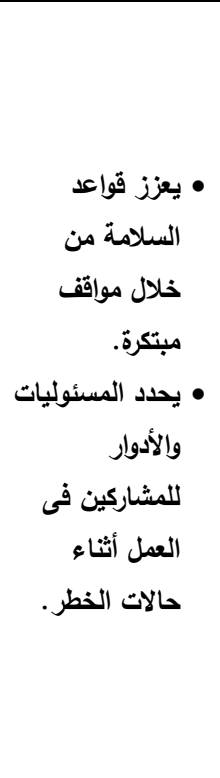 & • والستخدم تقنيات & 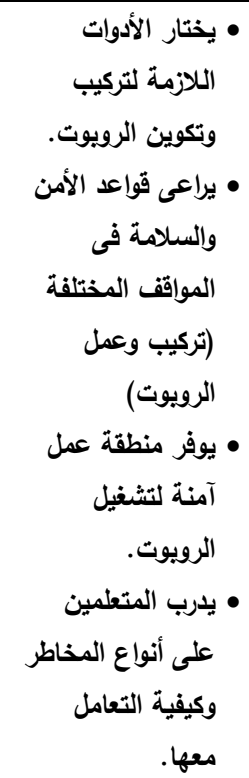 & والساسيات الأمن & مجال الامن \\
\hline • يحلل المخاطر & • للتيوفر لوحاته عن كيفية & • • يوفر لوحات ارثادية & متطلبات الأمن & \\
\hline
\end{tabular}

$.7 \varepsilon$.

البحث التريوي 
المركن القومي للبحوث التبويةوالتنمية

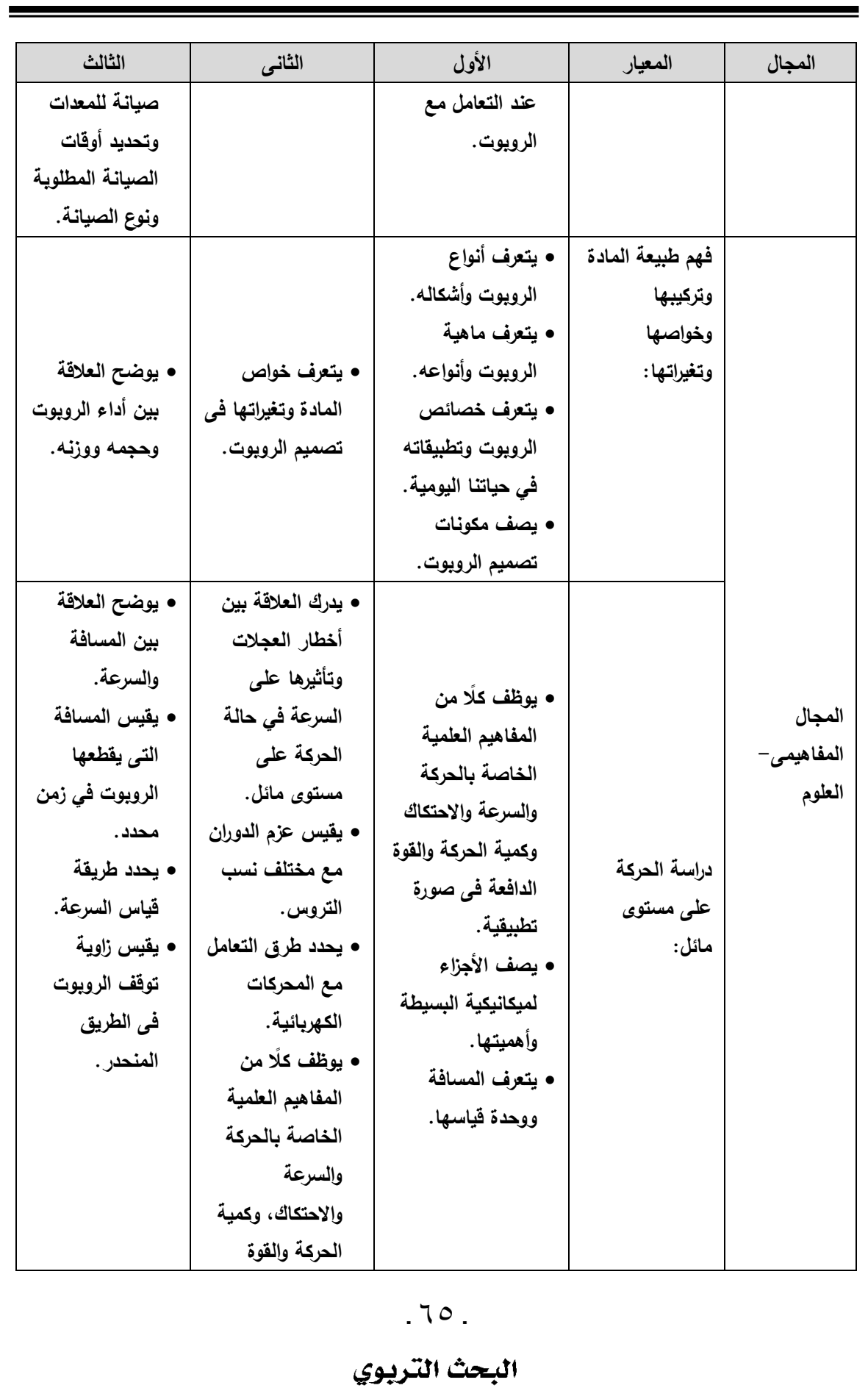




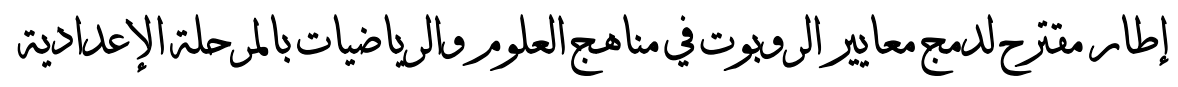

\begin{tabular}{|c|c|c|c|c|}
\hline الثالث & الثانى & الأول & المعيار & المجال \\
\hline & تطبيقية. & & & \\
\hline 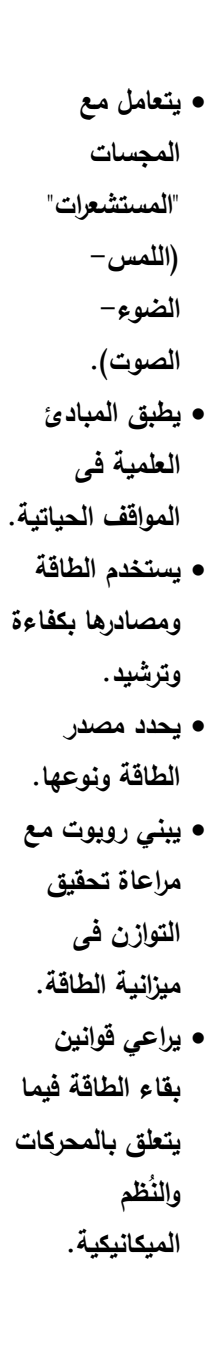 & 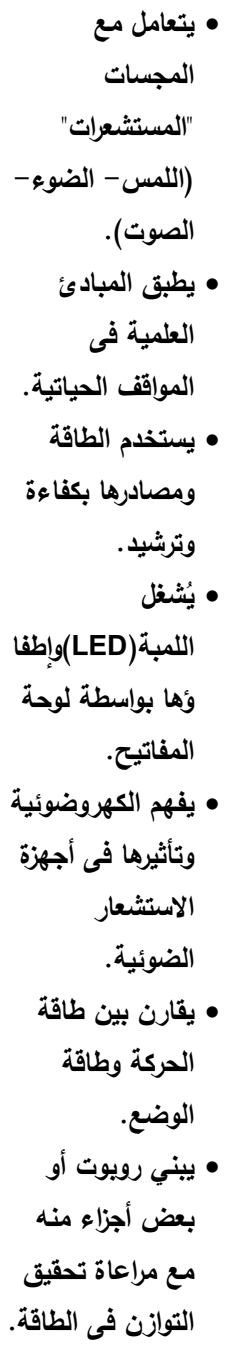 & 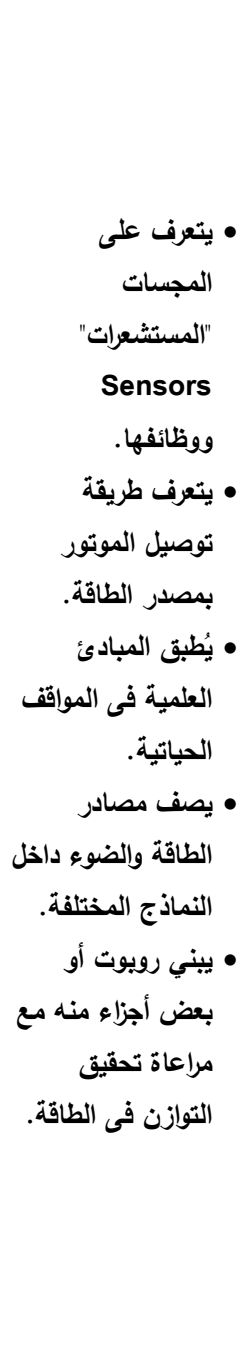 & وأيتعرف الطاقة & \\
\hline
\end{tabular}

.77.

البحث التربوي 
المركن القومي للبحوث التبويةوالتنمية

\begin{tabular}{|c|c|c|c|c|}
\hline الثالث & الثانى & الأول & المعيار & المجال \\
\hline \multirow[t]{2}{*}{ 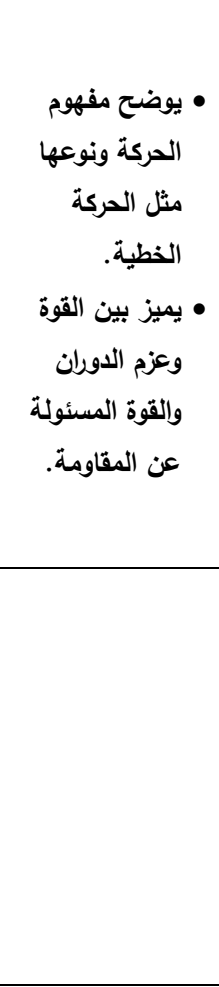 } & 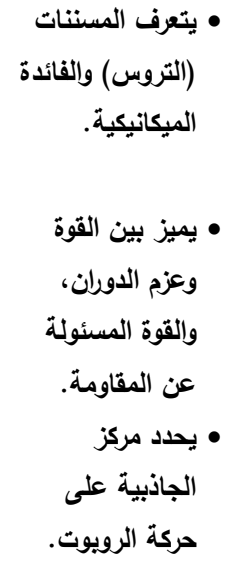 & & تعرف & \\
\hline & • العمهم دلالة العليات على العمليات بيعضد وعلاقة تلك & 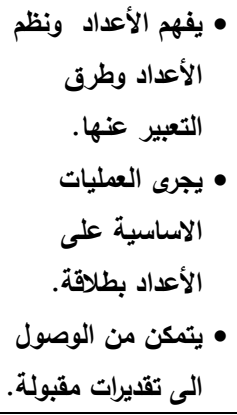 & عليها والعمليات & \multirow{3}{*}{ المجال الرياضي - المبات } \\
\hline • ب فيتخدم & 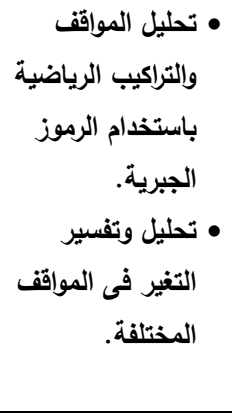 & • ليستخدم النماذج & الجبر & \\
\hline • تصديد المواقع & • الطبيق التحويلات & • ومليل خصائص & الهندسة & \\
\hline
\end{tabular}




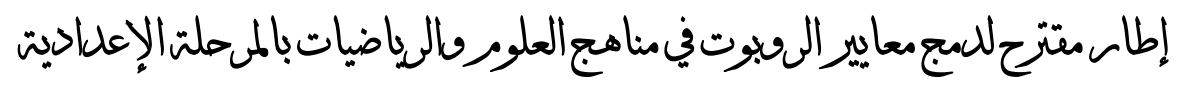

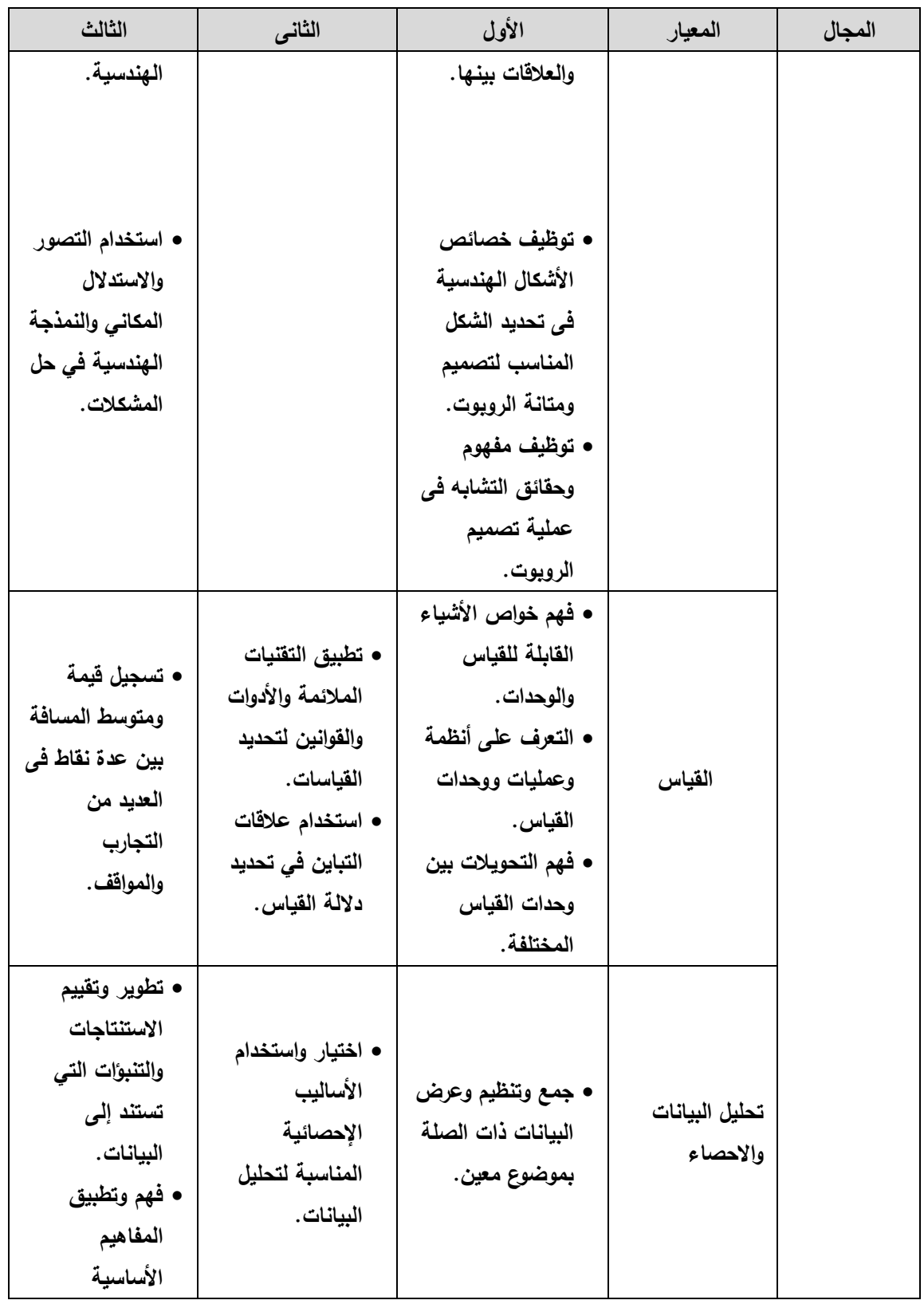

.71.

البحثث التريوي 
المركن الثومي للبحوث التبويةوالتنمية

\begin{tabular}{|c|c|c|c|c|}
\hline الثالث & الثانى & الأول & المعيار & المجال \\
\hline للإحتمال & & & & \\
\hline 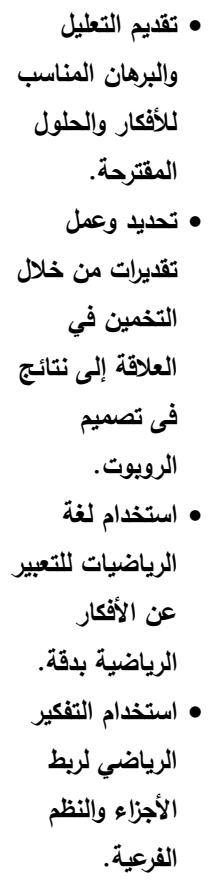 & • تُ تلوبيق العلاقات & • • • والتوظف مهارات & العملياضية & \\
\hline • يحدد احتياجات & 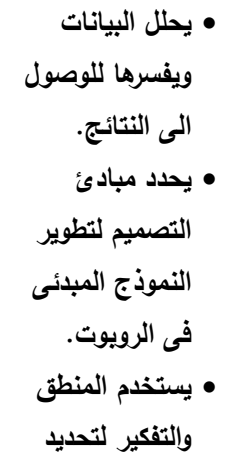 & • • • • يجمع المعلومات عن والوظيفة & التصميم & التصال الأداء \\
\hline
\end{tabular}




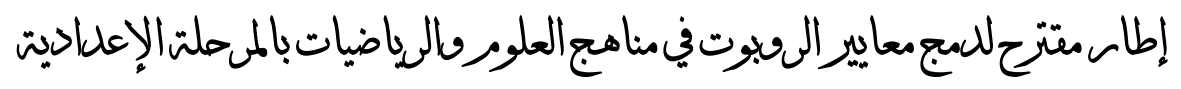

\begin{tabular}{|c|c|c|c|c|}
\hline الثالث & الثانى & الأول & المعيار & المجال \\
\hline 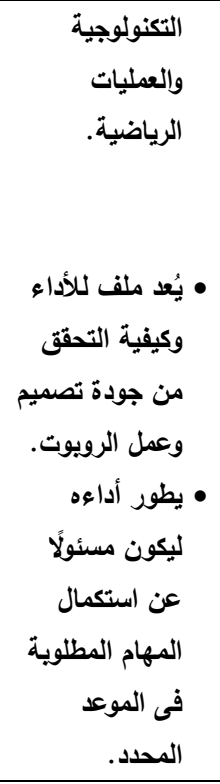 & والضاط القوة & • بطاء رويوت. & & \\
\hline 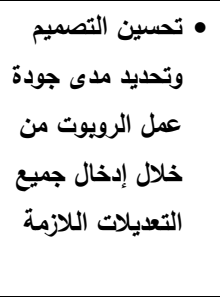 & • و تحديد أسباب & • تعديل الرويوت الذى تصميمه من & 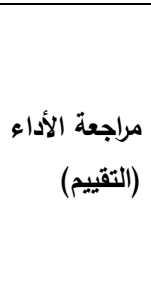 & \\
\hline • • • لتصميم أو تكييف & • • • التى تلتيد أهم الأجزاء & • • • • المكويد الأجزاء لنموذج & الصيانة & \\
\hline
\end{tabular}


المركن القومي للبحوث التبويةوالتنمية

\begin{tabular}{|c|c|c|c|c|}
\hline الثالث & الثانى & الأول & المعيار & المجال \\
\hline • فال الاجص وتفكيك & 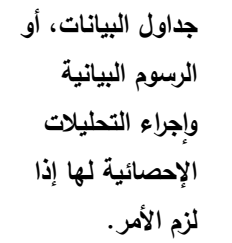 & & & \\
\hline 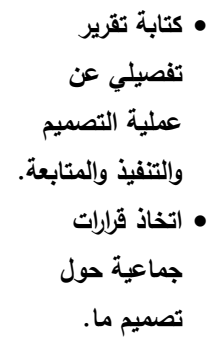 & 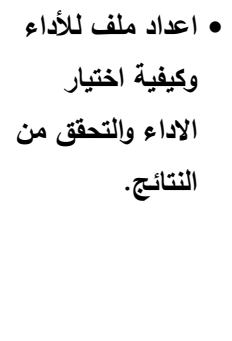 & 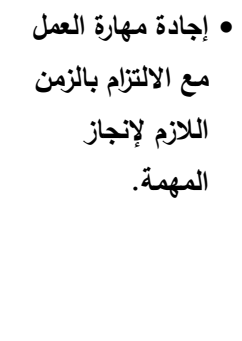 & إدارة العمل & \\
\hline 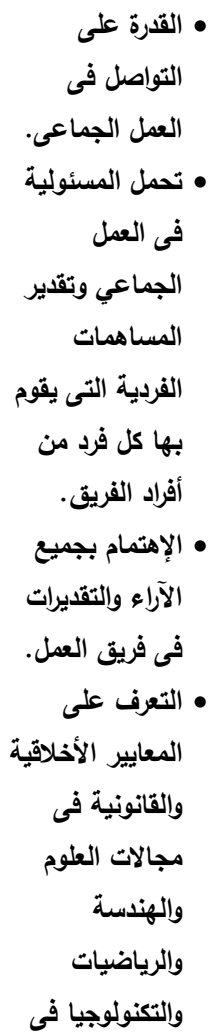 & 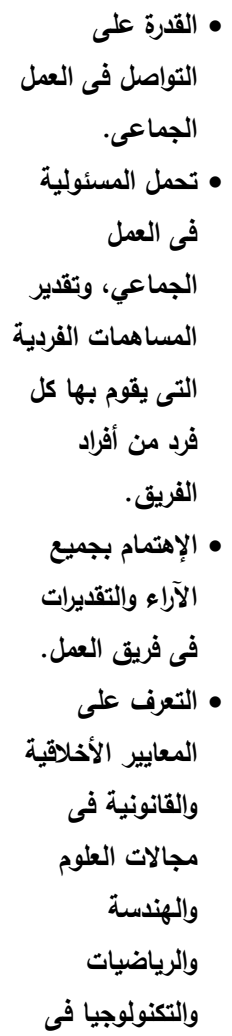 & 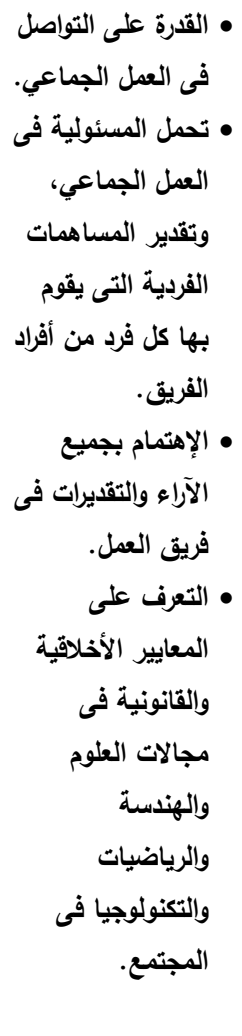 & الاتصال والتواصل & \\
\hline
\end{tabular}




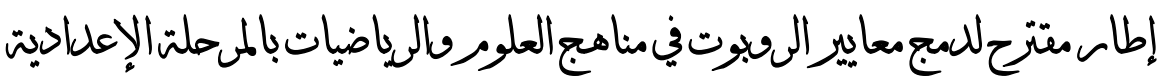

\begin{tabular}{|c|c|c|c|c|}
\hline الثالث & الثانى & الأول & المعيار & المجال \\
\hline المجتمع. & المجتمع. & & & \\
\hline
\end{tabular}

ثالثاً: للإجابـة عن السؤال الثالث: مـا التصور المقترح لوحدة دراسية فى

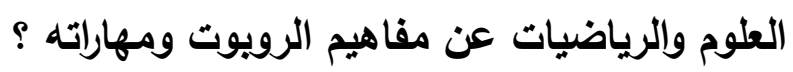

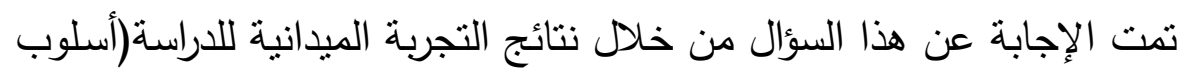

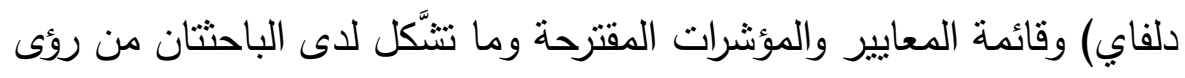

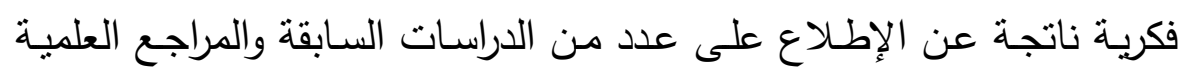

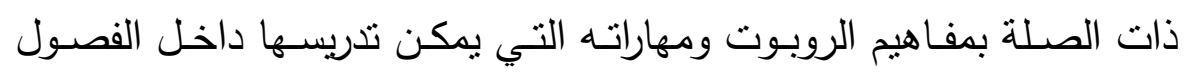

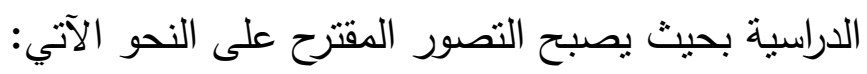

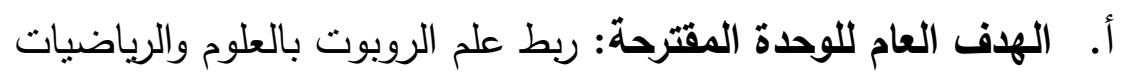

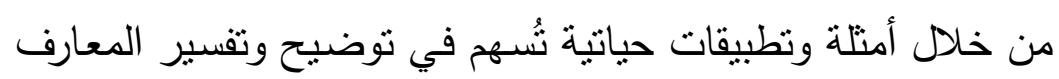

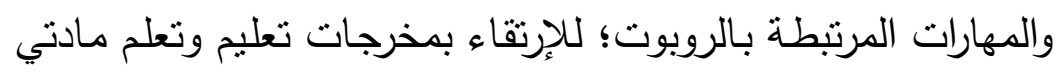
العلوم والرياضيات لدى طلاب المرحلة الإعدادية. ب. أُسس بناء الوحدة المقترحة: لرفع مستوى وعي طلاب المرحلة الإعدادية حول مفاهيم ومهارات الروبوت لهاءه من خلال توظيف المفاهيم العلمية والرياضية يجب مراعاة الأُسس الآتية: 1. ب. صياغة موضوعات الوحدة في ضوء معايير الروبوت المقترحة.

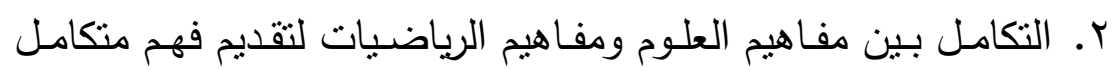
للعلوم في سبيل انتاج منتج علمي. .VY. البحث التربوي 


\section{المركن القومي للبحوث التبويةوالتنمية}

r. يمكن تتفيذ هذه الوحدة من قبل معلمو العلوم أو معلمو الرياضيات على حد سـواء حيث لكل مـادة تطبيقات مهاريـة مرتبطـة بالمفـاهيم

العلمبة.

ء. مساعدة المتعلمين على انماء تفكيرهم واستقلالهم العقلي.

ه. تشـيع المتعلمون على العمل في جماعات صغيرة لحل المشكلات والعمل سوياً بساعدهم على التعلم وتعديل التفكير واكتساب المهارات الاجتماعية المرغوبة.

7. الخبـرة هـي المحدد الأساسـي لمعرفـة المتعلم بحيث كلمـا مـرَّ بخبرة جديدة كلما أدى ذلك إلى ابداع أفكار جديدة.

V. تتميـة عـادات العقل والبحث العلمي، وإدارة تتظيم الوقت ومهـارات التحليل وإدارة المشروع مما يدفعهم نحو الابتكار والابداع في التصميم والبرمجة ومعالجة التحديات من خبراتهم التي يتعلموها. ^. يقوم المعلم بدور الوسيط الأساسي في التفاعل بين المتعلم والمعرفة بحيث يسـاعدهم على التواصـل وتبـادل الأفكار بين المتعلمين ممـا يسـاعدهم على نمو تفكيرهم، فالمعلم موجـه ومرشـد ومشـجع وميسر لحدوث التعلم.

ج. أهداف الوحدة المقترحة: تهـدف الوحـدة المقترحسة إلـى الارتقــاء بمخرجـات تعلـيم وتعلــم العـــوم والرياضـيات مسن خـلال ممارسـة المتعلمسين لمهـارات الروبـوت مسن خـلال إكسابهم ما يلي: - n 


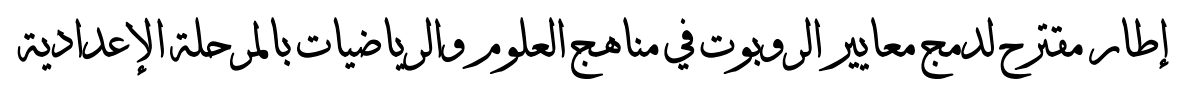

ا.تعزيز تعليم العلوم والرياضيات مـن خـلد اسـتمرار المـتعلم في تعلم الروبوت.

r. يراعسى قواعد الأمسن والسـلامة فـى المواقف المختلفـة (تركيب وعمـل

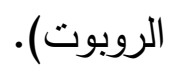

r.يختار الأدوات اللازمة لتصميم وبناء الروبوت.

ع. يتعرف ماهية الروبوت وأنواعه.

0. يصف مكونات تصميم الروبوت.

7. يصف الأجزاء الميكانيكية البسيطة وأهميتها لرونات

V. يتعرف على المجسات "المستشعرات" Sensors ورظائفها.

^. تطوير دهارات حل المشكلات من خلال بناء الروبوت لحل مشكلة ما. 9. يُطبق المبادئ العلمية فى المواقف الحياتية. • ا. يُجرى العمليات الأساسية على الأعداد بطلاقة. 11 إ. يتمكن من الوصول إلى تقديرات مقبولة.

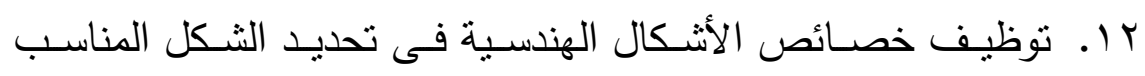
لتصميم الروبوت ومتانتة.

rا . . يجمع المعلومات عن التصميم والوظيفة ويفسرها فى ضوء النظريات ومثنات العلمية. ـ ا ـ يتعرف على خطوات تصميم الروبوت. 1 . . يكتسب مهارات التفكير وحل المشكلات من خلال بناء روبوت. 7 ا ـ إجادة مهارة العمل مع الالتزام بالزمن اللازم لإنجاز المهمة. .$\vee \varepsilon$. البحث التربوي 


\section{المركن القومي للبحوث التبويةوالتنمية}

V I ا. القدرة على التواصل الفعَّال فى العمل الجماعى. 1 ا. تحمل المسئولية فى العمل الجماعى وتقدير المساهمات الفردية التى يقوم بها كل فرد من افراد الفريق.

9 1 . الاهتمام بجميع الآراء والتقديرات فى فريق العمل. •r. r. يقدر العلم والعلماء وجهودهم.

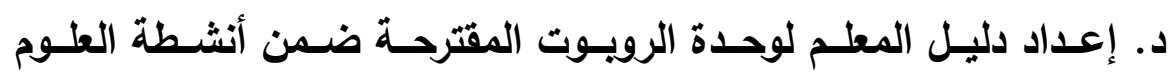
والرياضيات:

دليـل المعلـم هـو كتيـب يرجـع إليـه المعلـم عند تـدريس موضـوعات الروبوت ليسترشـ بـه عند اللزوم والحاجة إليه، حيث تم الاستفادة من قائمسة معايير الروبوت التي تم الاتفاق عليها من قِبل السـادة المحكمين من خـله جولات دلفاي الثناث، وكذللك فى ضـوء توزيع تلك المعايير على الصفوف الثلاث بالمرحلة الاعدادية، وتم الانتقاء منها وقد تم اتباع الآتي عند إعداد الدليل:

روعي أن تكون موضوعات وحدة الروبوت في دليل المعلم بها قدر من التكامل بين موضوعاتها وبين مفاهيم مادتي العلوم والرياضيات. تم مراعاة تبسيط المعرفة والتسلسل المنطقي للموضوعات. تم مراعاة ترابط الخبرات بعضها مـع بعض وكذلك مناسبة المعلومات

$$
\text { والدروس للمرحلة الإعدادية. }
$$

الدروس بنائية في مجملها بحيث تستخدم مفاهيم العلوم والرياضيات وبطبق ما تم تعلمه حول كيفية تصميم الروبوت وبنائه. 


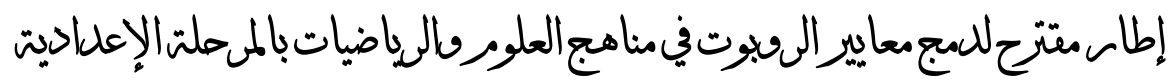

روعي أن ثُقَدَّم جميع المفاهيم العلمية الأكاديمية إلى المتعلمين من

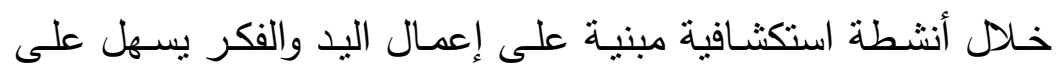
المتعلمين فهمها.

يحتوى هذا الدليل على عدد من الموضوعات التى يتخلاها أنشطة تـرتبط بمعـايير الروبـوت فـى المجـالات الثناثـة المقترحسة (الأمسن والسلامة- المجال المفاهيمى للعلوم والرياضيات- مجال الأداء)، وتم تضمين نماذج لمعايير ومؤشرات الروبوت في كل من مادتي العلوم والرياضيات وأخرى مشتركة على الموضوعات المختلفة. يختلف مستوى تضمين مفاهيم ومعايير العلوم والرياضيات من موضوع لآخر وفقًا لأهداف الموضوع والأنشطة المتضمنة وطبيعتها. موضوعات الوحدة جميعها تعليمية، بينما كان الموضوع الأخير في الوحدة على صورة مشروع. تـم عـرض الصــورة الأوليـة على السـادة المحكمين وتجريــب أحـد الموضوعات، وتم التعديل في ضوء التجريب. وقد اشتمل الاليل على العناصر الآتية: م مقدمـة وفكرة عامـة عن الروبـوت وأهميته، والفلسفة القائمسة

$$
\text { عليها الوحدة. }
$$

O توجيهات عامـة للمعلم وهـي بعض الإرشـادات والتوجيهات

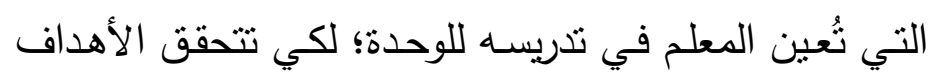

$$
\text { المرجوة من الوحدة. }
$$




\section{المركن القومي للبحوث التبويةوالتنمية}

$$
\text { O الأهداف العامة لتريس الوحدة. }
$$

O خطة السير في كل موضوع من الموضوعات الآتية:

$$
\begin{aligned}
& \text { الروبوت ومهامه. } \\
& \text { أنواع الروبوت ومجالات عمله. } \\
& \text { الإنسان وبرمجة الروبوت. } \\
& \text { صناعة ذراع الروبوت. } \\
& \text { مستثعر الروبوت. } \\
& \text { حركة الروبوت. } \\
& \text { بناء روبوت بسيط. } \\
& \text { مشروع الروبوت. }
\end{aligned}
$$

وقد تم الإتفاق على إعداد دروس تتضمن ثلاث مكونات أساسية وهي: خطوات إرشادية للمعلم: حيث توضح تلك الخطوات الإجراءات التى التى

$$
\text { تساعد المعلم فى تحقيق الأهداف المرجوة. }
$$

أوراق عمل للمتعلمين: والتى بطلب منهم استيفاءها؛ لضمان مثاركتهم الإيجابية فى عملية التعلم. قراعات إثرائيـة: توفر للمعلم وللمتعلمين المزبد من المعلومـات عن

$$
\text { الموضوع. }
$$

وبالانتهاء من إعداد هذا الدليل (ملحق 0) تكون قد تمت الإجابة عن السؤال الثالث من أسئلة الدراسة الحالية.

$$
\text { . V . }
$$




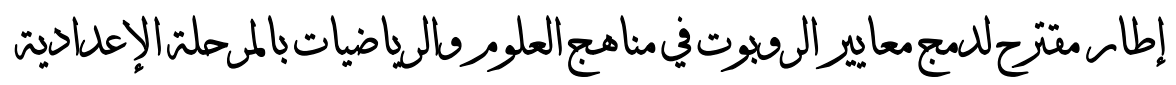

\section{توصيات الدراسة:}

في ضوء ما توصلت إليه الدراسة من نتائج توصي الدراسة بالآتي:

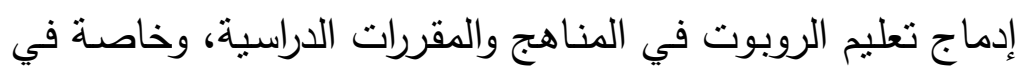
مادتي العلوم والرياضيات.

الاهتمام بإكساب المتعلمين مفاهيم الروبوت ومهاراته.

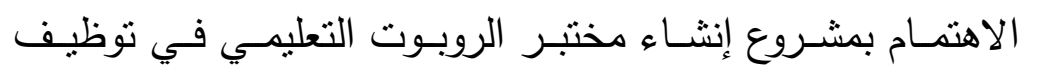
مفاهيم ومهارات مادتي العلوم والرياضيات. عمل برامج تدريبية للمعلمين حول كيفيـة تطبيق المفاهيم العلمية ولية والرياضية من خلال أنشطة الروبوت.

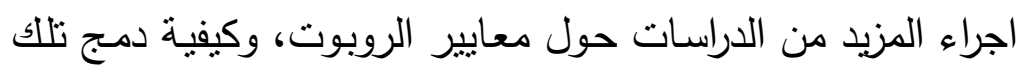
المعايير في المناهج الدراسية المختلفة. هقترحات الدراسة:

في ضوء نتائج الدراسة الحالية يُمكن اقتراح الدراسات الآتية: تطبيق دراسـات وبحوث مشـابهة على معـايير الروبوت بالمراحل التعليمية المختلفة كالمرحلة الابتدائية والثانوية.

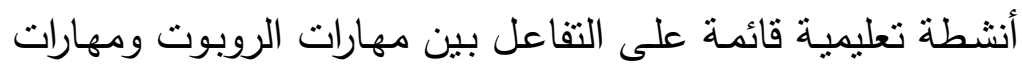
القرن الحادي والعشرين في العلوم والرياضيات.

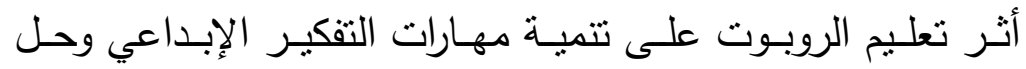
المشكلات ومهارات العمل لدى المتعلمين. 


\section{المركن القومي للبحوث التبويةوالتنمية}

إجـراء دراسـة مقارنـة بـين مسـتوى التعامـل مـع تقنيـات الروبـوت التعليمسي والـذكاء الاصــناعي لـدى تلاميـذ المرحلـة الإعداديـة، ومسنتى التعامل مع تقنيات الروبوت التعليمي والذكاء الاصطناعي لدى معلميهم.

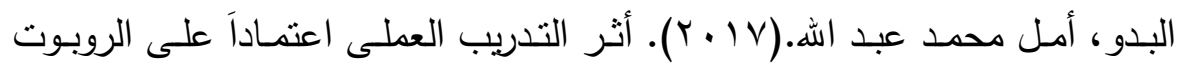
التعليم في تتميـة التحصيل الرياضـى لطالبات الصف الثانى عثر علمى الثى

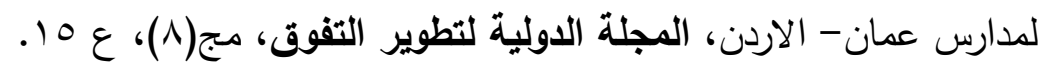
البعلبكي، منير .(10 • ( ). قاموس المورد، بيروت: دار العلم للملايين.

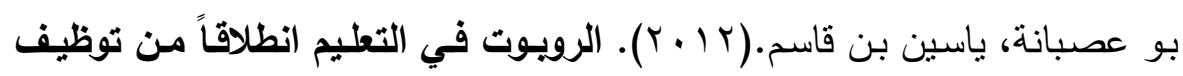
استراتيجية STEM ، مدرسة تاونزة العلمية، الجزائر.

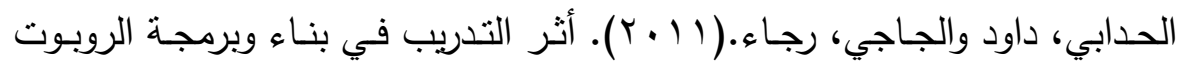
على تتمية التفكير الابداعي ومهارات التفكير العلمي لدى عينة من الطلبة

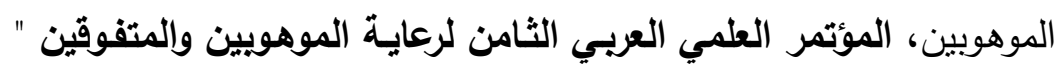

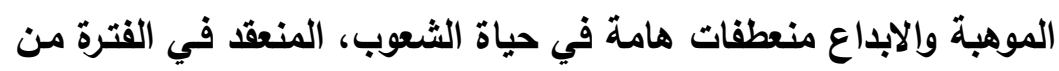

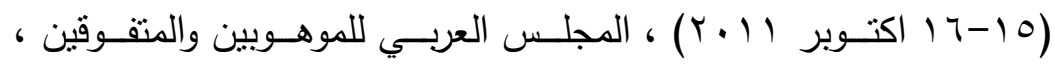

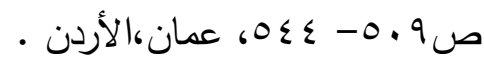
حمدان، سـارة.(r ( • Y). الروبوت في العـالم العربي. تحديات وطموحات وتجارب عربية، المؤتمر العلمي العربي الثاني لعلوم الرويوت والذكاء الاصطناعي، 


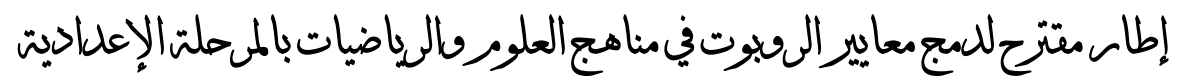

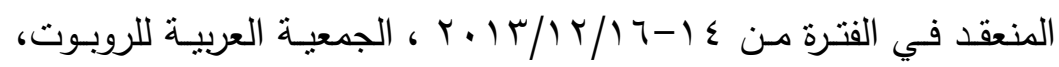
عمان- الأردن.

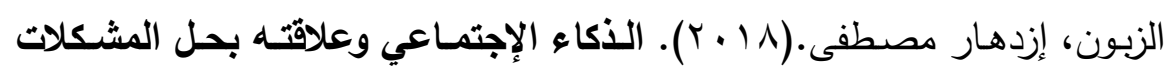
لاى الطلبة المشاركين وغير المشاركين في برامج الرويوت التعليمية في الإني

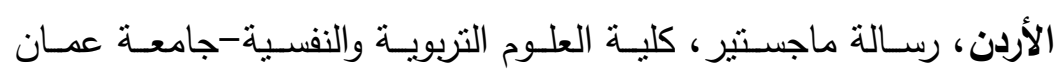
العربية، عمّان.

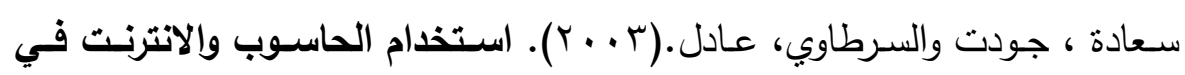
ميادين التربية والتعليم، عمان: دار الثروق.

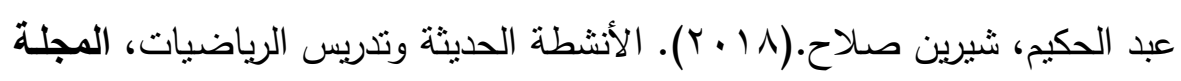

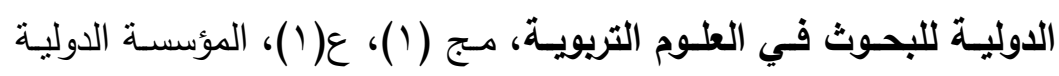
لأفاق المستقبل: نالين(استونيا).

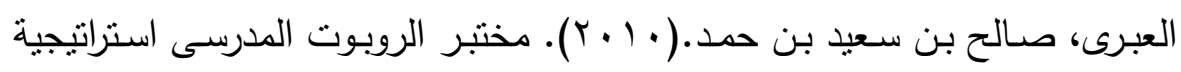

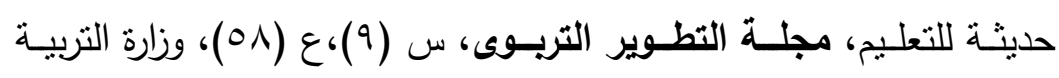

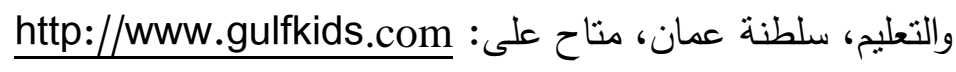

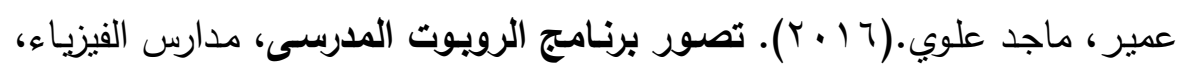

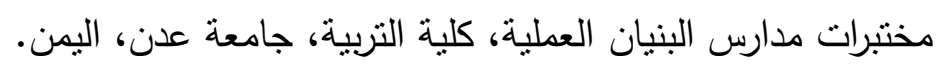

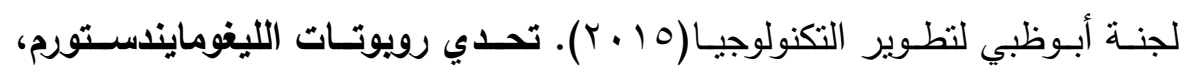

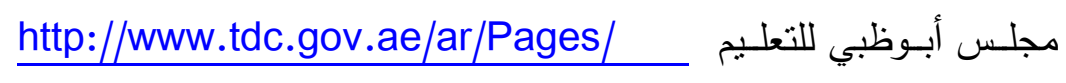
lemaprogram.aspx

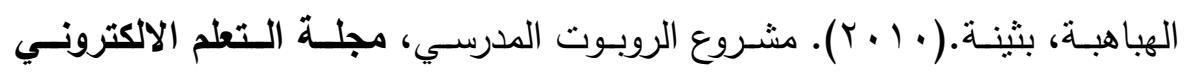

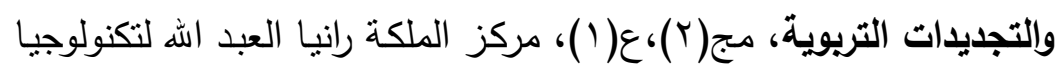




\section{المركن القومي للبحوث التبويةوالتنمية}

التعليم، وزارة التربيـة والتعليم ، المملكة الأردنية الهاثـمية ، ص ص ع؟.YT

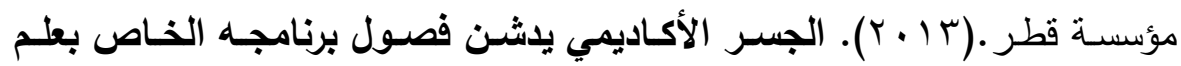

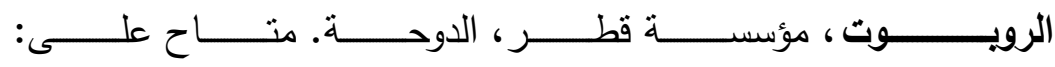
https://www.qf.org.qa/news-ar/59

وزارة التخطيط والمتابعة والإصلاح الإداري.(0 1 • ب). استراتيجية التتمية المستدامة-

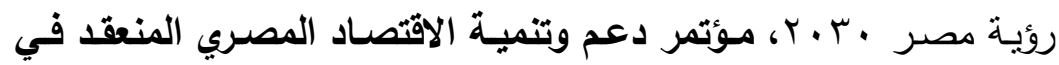

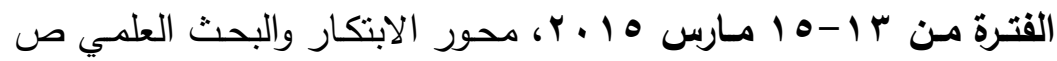

$$
\text { . } \Sigma \Lambda-\Sigma Y
$$

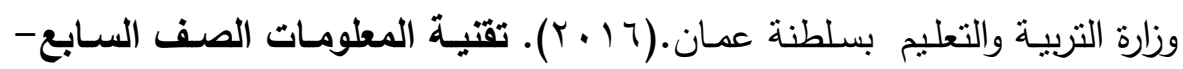
الفصل الدراسى الثانى، مركز العلوم والتكنولوجيا بمحافظة الداخلية، سلطنة

$$
\begin{aligned}
& \text { عمان. }
\end{aligned}
$$

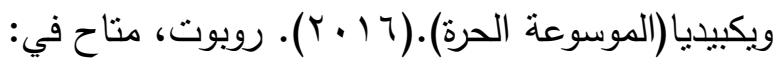

https://ar.wikipedia.org/wiki/\%D8\%B1\%D9\%88\%D8\%A8\%D 9\%88\%D8\%AA

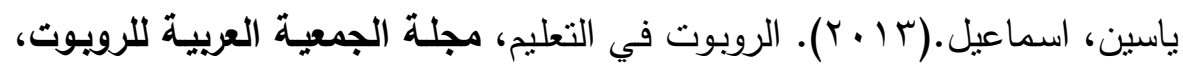

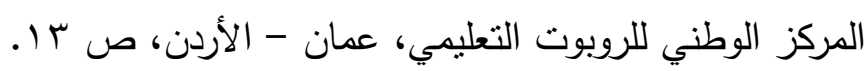

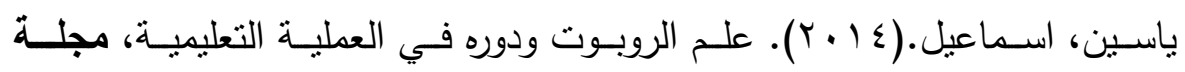

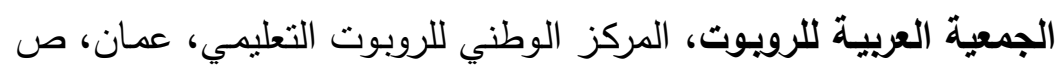

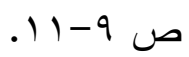




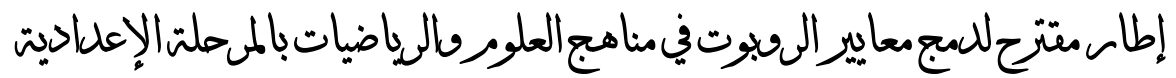

Altin, H. \&Pedaste, M.(2013).learning approaches to applying robotics in science education, Journal of Baltic Science Education, Vol. 12, No. 3, ISSN 1648-3898

American Society for Engineering Education,(2013). Transforming a Middle and High School Robotics Curriculum, 120 th ASEE Annual conference and exposition available at: file:///C:/Users/ Ahmed\%20Mohsen/drive\%20c/Downloads/ASEE_201 3_Final.pdf

Bianco, Andrew S.( 2014). Starting and Teaching Basic Robotics in the Classroom: Modern, Engaging Engineering in Technology Education,Technology and Engineering Teacher, v73 n7 p32-38.

Bredenfeld, A., Hofmann, A., \& Steinbauer, G. (2010). Robotics in education initiatives in Europe: Status, shortcomings and open questions. In E. Menegatti (ed.), Proceedings of SIMPAR 2010 Workshop, International Conference on Simulation, Modeling and Programming for Autonomous Robots. Darmstadt, Germany (pp. 568-574)

Carnegie Mellon Robotics Academy (2017).US Standards grids, curriculum for stem excellence (Robot Science featuring Data Logging) available at: https://www. cmu.edu/roboticsacademy/roboticscurriculum/index.ht $\underline{\mathrm{ml}}$

Catlin, D., \& Balmires, M. (2010). The e-Robot project: A longitudinal on-line research collaboration to investigate ERA principles. In E. Menegatti (ed.), Proceedings of SIMPAR 2010 Workshop,

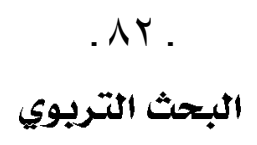




$$
\text { المركن القومي للبحوث التبريةوالتنمية }
$$

International Conference on Simulation, Modeling and Programming for Autonomous Robots. Darmstadt, Germany (pp. 411-420)

Chung, C. J. ChanJin; Cartwright, Christopher; Cole, Matthew(2014). Assessing the Impact of an Autonomous Robotics Competition for STEM Education,Journal of STEM Education: Innovations and Research, v15 n2 p24-34 Jul-Sep

Cincelli, S., Festi, G., Finotti, F., Lenzen, D., \& Monfalcon, S. (2010). Teaching with robotics: different experiences at school after the TERECoP courses. In E. Menegatti (ed.), Proceedings of SIMPAR 2010 Workshop, International Conference on Simulation, Modeling and Programming for Autonomous Robots. Darmstadt, Germany (pp. 429-438).

Denis, B. (2001). Collaborative learning in an educational robotics environment. Computers in Human Behavior, 17(5-6), 465-480

Egypt VEX Robotics Competition (2016): VEX Robotics Competition, Bibliotheca Alexandrina, Edutainment center @ Family park Available at: https://www. robotevents.com/robot-competitions/vex-roboticscompetition/re-vrc-16-3280.html

Giannakopoulos, N. (2009). Experiences from WRO 2009 competition and verifications about the robotics incorporation in the school. Paper presented at the Lessons Learnt from the TERECoP Project and New Pathways into Educational Robotics across EuropeAthens. 


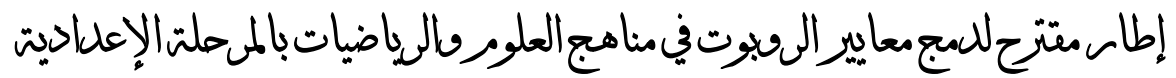

Igor, M.v. \& Eyal, H.(2003). School Graduation Project in Robot Design: A Case Study of Team Learning Experiences and Outcomes, Journal of Technology Education,Vol.14 No.2, Spring 2003,(EJ667401)

Laughlin, Sara Rose(2013).Robotics: Assessing Its Role in Improving Mathematics Skills for Grades 4 to 5 ProQuest LLC, Ph.D. Dissertation, Capella University ERIC Number: ED552844.

Lego Mindstorms (2011).Teacher Guide. the LEGO Group available at: http://education.lego.com

Mubin, O.; Stevens, C. J.; Al Mahmud, Suleman, and Dong, Jian-Jie (2013) . A Review of the Applicability of Robots in Education, Technology for Education and Learning, pp1-7

Nemiro, Jill; Larriva, Cesar; Jawaharlal, Mariappan (2017).Developing Creative Behavior in Elementary School Students with Robotics,Journal of Creative Behavior, v51 n1 p70-90

Norton, S. J., McRobbie, C. J., \& Ginns, I. S. (2006). Problem solving in a middle school robotics design classroom. Research in Science Education, 37(3), 261-277

Pedaste, M., \& Sarapuu, T. (2006). Developing an effective support system for inquiry learning in a Web-based environment. Journal of Computer Assisted Learning, 22 (1), 47-62. doi: 10.1111/j.1365-2729.2006.00159.x

Pedaste, M., Maeots, M., Leijen, A. \& Sarapuu, T. (2012). Improving students' inquiry skills through reflection and self-regulation scaffolds. Technology, Instruction, Cognition and Learning, 9 (1-2), 81-95.

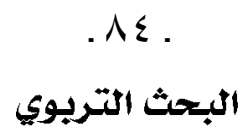


Polk, I. (2005). "RoboNexus 2005 robot exhibition virtual tour". Robonexus Exhibition 2005, San Francisco Robotics Society of America;San Jose in time of San Jose Blues Festival; available at: http://www.virtuar. com/click/2005/robonexus/

Robotics Education Symposium Science, Technology,

Engineering, \&Mathematics (2006). "Standards-Based

Robotics Competition Curriculum Development Framework, Technology Student Association , 1914 Association Drive, Reston, VA ,20191, Available at: www.tsaweb.org \& www. tsarobotics.org

Soares, F., Leão, C. P., Santos, S., Ribeiro, A. F., \& Lopes, G. (2011). An early start in robotics: K-12 case-study. International Journal of Engineering Pedagogy (iJEP), $1(1), 50-56$.

Techno Future Jordan (2015). JUNIOR FIRST LEGO League ( Jr.FLL), Jr.FLL Waste Wise Challenge 20152016, Jr.FLL Think Tank Challenge 2014-2015

World Robot Olympiad (WRO) (2014). World Robot Olympiad Oman Available at: http://www.wroboto.org/wro2014 Available at: https://www.facebook.com/ $\underline{\text { TechnoFutureJordan }}$ 